\title{
Corporate Governance and Cost of Capital: Evidence from Emerging Market
}

\author{
Muhammad Yar Khan ${ }^{1}\left(\mathbb{D}\right.$, Anam Javeed ${ }^{2}{ }^{-}$, Ly Kim Cuong ${ }^{3}$ and Ha Pham ${ }^{3, *}$ \\ 1 Department of Management Sciences, COMSATS University Islamabad, Wah Campus 47040, Pakistan; \\ muhammadyar@ciitwah.edu.pk \\ 2 Department of Management Sciences, University of Wah, Wah 47040, Pakistan; dr.anam.javeed@uow.edu.pk \\ 3 Faculty of Finance-Banking, Ho Chi Minh City Open University, Ho Chi Minh City 70000, Vietnam; \\ cuong.lk@ou.edu.vn \\ * Correspondence: ha.p@ou.edu.vn
}

Received: 28 June 2020; Accepted: 15 September 2020; Published: 9 October 2020

\begin{abstract}
This study used a researcher self-constructed corporate governance index as a proxy to measure the firm-level corporate governance compliance and disclosure with the 2002 Pakistani Code of Corporate Governance, to examine the relationship between corporate governance and cost of capital. We found a negative and significant association between the Pakistani Corporate Governance Index (PCGI) and block ownership with the firm-level cost of capital. On average, better-governed Pakistani listed firms tend to be associated with a lower cost of capital than their poorly governed counterparts are. As an emerging market, good corporate governance practices are mainly related to minimise corporate failure and assist firms in attracting capital at a lower cost.
\end{abstract}

Keywords: corporate governance index; cost of capital; ownership structures; government; director; Pakistan

\section{Introduction}

The 1997 Asian financial crises were an evolving landscape for Asian policymakers and companies. Several institutional and policy weaknesses were uncovered by these crises and led to numerous economic reforms in the region. According to Demise (2006) regulations and guidelines have been legislated in developing countries with the support of international organisations such as the World Bank and Organization for Economic Cooperation and Development (OECD). The Pakistan Stock Exchanges have not been spared these significant reforms in the way companies are managed and controlled, which have swept across the world in recent times. Corporate governance reforms were the most critical part of those reforms that were aimed to restore investors' confidence. With respect to adopting corporate governance codes, and as the case with most developing countries, Pakistan issued its corporate governance code in March 2002, which is regarded as an essential development for corporate governance reforms. This corporate governance code has been established by the combined efforts of the Securities and Exchange Commission of Pakistan (SECP) and the Institute of Chartered Accountants of Pakistan (ICAP). The requirements of the code are comprehensively influenced by UK corporate governance style (Tariq and Abbas 2013). The code has a series of governance provisions that are focused on three main areas, including better disclosure, strengthening of internal control systems, and reforms of the board of directors, with the concern of making it accountable to the stockholders. Claessens and Yurtoglu (2013) find that firms with better corporate governance gain more accessible access to financing and better performance. The critical question is whether adopting similar corporate governance provisions from developed countries can effectively assist Pakistani firms to increase their firm value by reducing their cost of capital. 
In addition to the level of corporate governance compliance, this study also investigates the value-creating role of corporate governance mechanisms, using a different approach to the previous studies (i.e., using individual corporate governance variables and investigating the impact corporate governance on the cost of equity only) through the cost of capital as a value-creating variable. The previous studies examine the nexus between individual governance variables and financial performance, such as Return on Assets (ROA), return on equity (ROE), and Tobin's Q. The current study investigates the effect of firm-level governance mechanisms and ownership structure on firm-level cost of capital by constructing a unique corporate governance index. The index is constructed by using another method, such as an unweighted corporate governance index based on the 2002 Pakistani Code of Corporate Governance. Pakistan has adopted the Anglo-American model in order to improve corporate governance standards in its corporate sector. This may raise a critical question as to whether the Anglo-American model of corporate governance is appropriate, given the differences in culture between Pakistan and those countries. Therefore, our study draws necessary policy implications for other emerging economies like Pakistan.

One of the main objectives of corporate governance is to protect outside investors, including both creditors and shareholders, against expropriation by managers or controlling shareholders (Cumming et al. 2019; La Porta et al. 2002; Ilyas and Jan 2017). Corporate governance mechanisms, such as better and timely disclosure, independent non-executive members working on the board of directors and in audit committee, and independent auditors, are expected to reduce the risk of investors and firms' cost of capital in several ways. First, better corporate governance serves to monitor controlling shareholders or the manager's actions, minimising the risk of expropriation (Ilyas and Jan 2017; Chen et al. 2009). Second, better corporate governance can reduce information asymmetry between the controlling shareholders and other outside investors (Verrecchia 2001), and, hence, it reduces the uncertainty of future expected cash flows (Clarkson et al. 1996). Finally, as suggested by Lombardo and Marco (1999), better corporate governance disclosure reduces the monitoring cost of outside investors, and, thus, they are likely to demand a lower required rate of return, which can increase firm value. In this study, the two main themes of corporate governance structures are used to develop various hypotheses: The first theme is the firm-level corporate governance index, and the second is ownership variables, including (i) director, (iii) institutional, (iii) government, (iv) block, and (v) foreign ownership.

Using a sample of 160 Pakistani firms from 2003 to 2013 and the governance data, which were collected manually from the annual reports, this paper investigates seven closely related and critical corporate issues that are related to the compliance of governance rules. We find that firms with a high level of corporate governance standards have a lower cost of capital. Hermalin and Weisbach (2019) suggest that assessment is a crucial factor in understanding and regulating corporate governance. Our finding suggests that good corporate governance practices in Pakistan are intended to safeguard minority shareholders and creditors among other outside investors against the expropriation of controlling shareholders. Firms with a high level of director ownership are found to have a higher cost of capital. Our finding is in line with the prediction of agency theory: A higher level of director ownership may worsen agency problems (Demsetz and Lehn 1985). Pakistani firms with a higher level of foreign investors are found to have a higher cost of capital than those with less or no foreign investors. This positive relationship between foreign ownership and the cost of capital is consistent with the prediction of information asymmetry. This issue is relatively higher among foreign investors because of language and distance obstacles (Huafang and Jianguo 2007), which may lead to a higher cost of capital. We did not find any evidence for institutional ownership and government ownership.

This paper contributes as follows. First, distinctively, the current study uses a researcher's self-constructed corporate governance index (Khan 2016) as a proxy, to measure the firm-level corporate governance compliance and disclosure with the 2002 Pakistani Code of Corporate Governance (PCCG 2000). The adoption of self-constructed the corporate governance (CG) index as a methodological approach is justified as follows. Briefly, the use of the Pakistani Corporate Governance Index (PCGI) is 
suitable, as (i) it is directly applicable to Pakistani context, (ii) the PCGI is designed to incorporate most of the CG aspects that have been suggested by the literature, and (iii) there is no theoretical guidance which offers a criterion for the selection of indices to be used in the study. Furthermore, it is in line with many recent studies (e.g., Ntim et al. 2012; Hooghiemstra 2012; Allegrini and Greco 2013; Tariq and Abbas 2013) that investigated the level and determinants of CG compliance by relying on national (e.g., King 2002) codes in constructing their CG indices (Hooghiemstra 2012). The PCGI contains 70 CG provisions covering five broad aspects: (i) the board of directors; (ii) internal auditing and committees; (iii) shareholders right; (iv) transparency and disclosure; and (v) internal control, external auditor, and risk management. The PCGI is constructed from the PCCG 2002. The listing rules were also used as an additional source, in order to develop a comprehensive index. Table A2 in Appendix B explains each provision and the source included in the PCGI. An analysis of corporate governance literature advocates that a good number of studies have been conducted in developed markets to analyse the effectiveness of corporate governance codes. Therefore, investigating corporate governance compliance and disclosure in different regulatory, cultural, institutional, and corporate governance contexts is essential, as it is likely to come up with different findings. On one hand, a considerable number of studies analysing the determinants of corporate governance compliance have been performed in the developed markets with generally similar corporate governance and institutional settings. On the other hand, factors influencing the level of corporate governance compliance and disclosure in emerging markets like Pakistan, where empirical findings are rare, are vital in providing a broader picture of corporate governance compliance and disclosure behaviour.

Second, using one of the largest manually collected datasets on corporate governance in emerging markets directly from firms' annual reports (i.e., a sample of 160 Pakistani listed firms from 2003 to 2013, with 1760 firm-year observations), this study offers, for the first time, direct evidence on the effectiveness of corporate governance reforms in Pakistan. Precisely, it provides detailed findings on the level of corporate governance compliance and disclosure with the PCCG 2002 among listed firms. Similar to the limited number of prior studies in emerging markets, the introduction of the PCCG 2002 facilitates uniformity and convergence of corporate governance practices. The findings recommend that corporate governance practices still differ widely among Pakistani listed firms over the eleven-year period examined. Third, the current study offers empirical evidence on how traditional ownerships influence the level of corporate governance compliance and disclosure among Pakistani listed firms for the first time.

This paper is organised as follows. Section 2 relates to the institutional context of Pakistan. Section 3 presents hypothesis development. Section 4 explains data and empirical estimation. Section 4 provides the data sample and summary statistics. Section 5 reports the empirical findings. Section 6 concludes the paper.

\section{Institutional Context: Pakistan Code of Corporate Governance}

Pakistani policymakers established the SECP in the late 1990s, to bring CG reforms to the country. In 2002, the SECP introduced important CG regulations known as the Pakistani Code of Corporate Governance (PCCG). Noticeably, the introduction of the Pakistani Code of Corporate Governance has improved the corporate governance standards in the country. As shown in Figure 1, the mean score of PCGI has increased from 20.6\% in 2003 to $85.2 \%$ in 2013, with an overall increase of $64.6 \%$ in eleven years. Such an increase in the level of disclosure may decrease information asymmetry (Al-Bassam et al. 2018; Al-Nodel and Hussainey 2010; Al-Abbas 2009; Khan et al. 2017). 


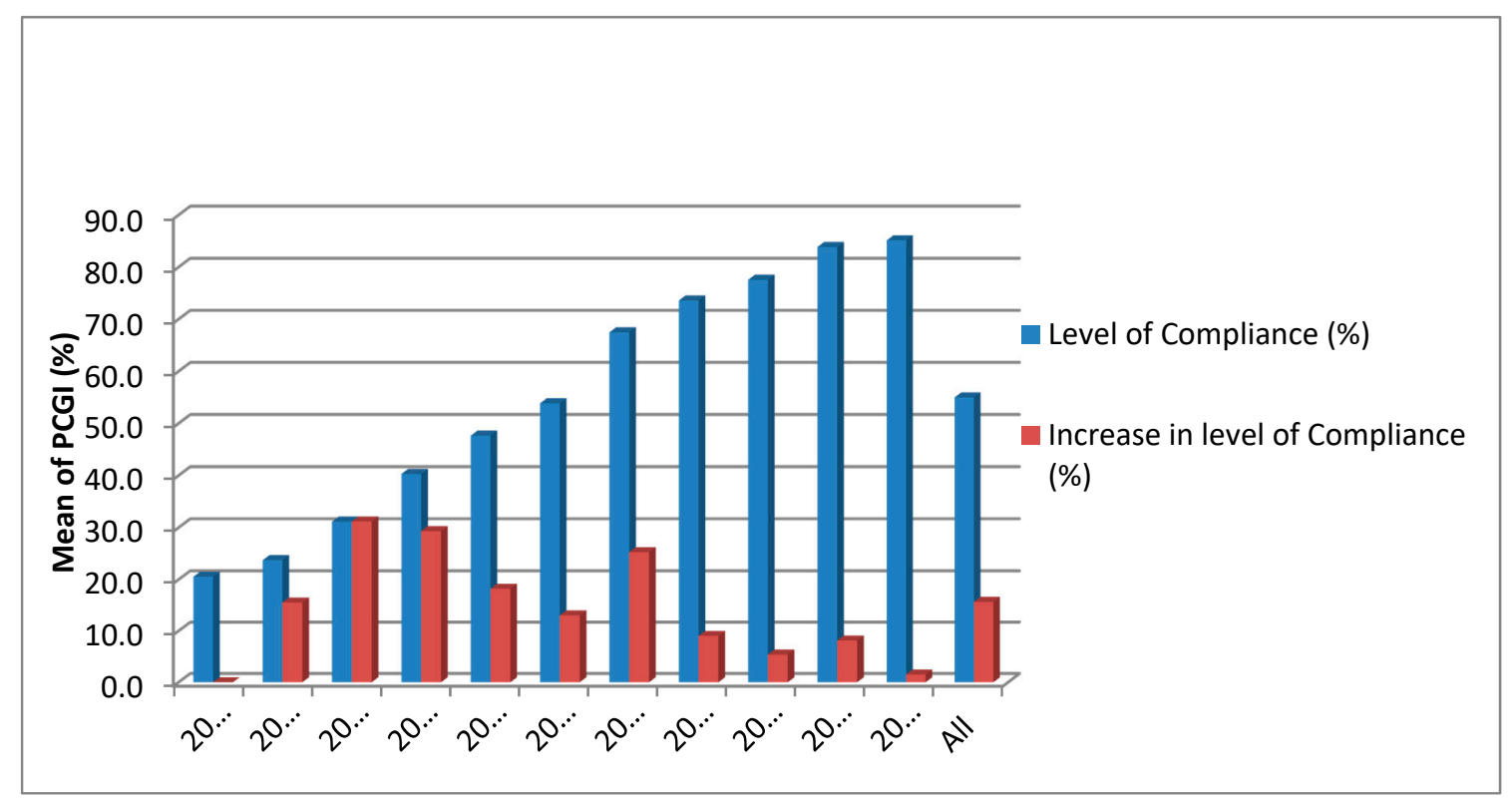

Figure 1. The compliance level with Pakistani Corporate Governance Index (PCGI) based on the full sample. Note on the authors' calculation: The level of compliance is calculated by using the yearly average of PCGI. The year-wise increase in the level of compliance is also presented in Figure 1. The blue bar of the graph shows a constant increase in the level of compliance over the sample period. However, the increase in the level of compliance varies from year to year. For instance, in the beginning, years, there is a rise of 10 to $30 \%$, which decreases to less than $5 \%$ in the last years. This is because most of the firms started following the corporate governance (CG) standards.

Pakistan makes it unique for this study due to some reasons. First, like most countries in the developing world, Pakistani companies have controlling shareholders in the form of family ownership. This provides the controlling shareholders with both the incentive in the case of low cash flow rights and opportunity in the case of high free cash flows to expropriate outsider minority shareholders (Bozec and Laurin 2008). Similarly, strong corporate governance and investor protection found in the developed countries are believed to be more effective, as compared to Asian countries (Dyck and Zingales 2004). Notably, the Pakistani corporate setting shares some level of similarities and differences with the UK corporate environment.

On the one hand-contrary to the Berle and Means model of separation of ownership and control-foremost Pakistani firms' ownership structure bears a resemblance to a concentrated family ownership structure. Arguably, this concentrated ownership structure of Pakistani firms is different from those of the Anglo-American structure of dispersed ownership. The corporate governance mechanisms formulated by following markets with dispersed ownership structure may not offer the right remedy to the governance issues for a market with concentrated ownership. Therefore, this study may provide exciting and different findings than those from the Anglo-American countries.

Second, Pakistan's constitution requires that all laws conform to Islam. Although the fiduciary duties set by the Security and Exchange Commission of Pakistan are initially based on Anglo-American common law and shareholding model of corporate governance, more importantly, they must also conform to Islamic business ethics (Ibrahim 2006; Arslan and Abidin 2019). In this regard, strong Islamic notions are incorporated in Pakistani corporate governance code, such as accountability, transparency, and responsibility. These can have important implications for the level of CG compliance and disclosure (Abu-Tapanjeh 2009; Ahmad 2011; Ilyas and Jan 2017).

Third, Pakistan has adopted the Anglo-American model to improve corporate governance standards in its corporate sector. The agency problem is expected to be different in developing countries like Pakistan, due to the nature of ownership structures, where the conflict of interests is between minority (outsider) and majority (insider) shareholders instead of managers and shareholders as is the 
case in UK and US (Bozec and Bozec 2011). Therefore, this study sheds light on whether the adaptation of commonly accepted corporate governance standards, as proposed by Anglo-American countries, can improve the corporate governance practices in emerging economies like Pakistan.

\section{Hypothesis Development}

\subsection{Firm-Level Corporate Governance and Cost of Capital}

Theoretically, corporate governance encompasses different mechanisms that can assure creditors and shareholders of the firm on a return on their investments (Shleifer and Vishny 1997). In the case of most developing countries, when firms have controlling shareholders (see Claessen et al. 2000; Faccio and Lang 2002), corporate governance mitigate agency problems between insiders shareholders and outside investors, including both creditors and minority shareholders. Insider shareholders enjoy the control of the firm's operation by having a large portion of voting rights and, therefore, may expropriate outside investors, including minority shareholders and creditors (Cumming et al. 2019; La Porta et al. 2002). In this context, good corporate governance practices are intended to safeguard minority shareholders and creditors among other outside investors against the expropriation of controlling shareholders (Ilyas and Jan 2017). Arguably, when investors feel protected, they are motivated to participate in the capital market more active and are more likely willing to pay more for such firms' securities. Firms can enjoy a lower cost of raising capital, which in turn raises the firms' value. Thus, we postulate the first hypothesis:

Hypothesis 1. There is a statistically significant and negative relationship between firm-level corporate governance and firms' cost of capital.

\subsection{Ownership Structures and Cost of Capital (COC)}

In this subsection, the hypotheses of different ownership variables are developed with firms' cost of capital. The ownership variables include director ownership, institutional ownership, government ownership, block ownership, and foreign ownership.

From a managerial signalling perspective, Bebchuk and Weisbach (2010) argue that the directors have more information about the firms, compared to outsiders (minority shareholders and creditors). Therefore, it is more likely that the executives can use the firms' statistics for the personal interests that shift risk to, rather than share risk with, outside shareholders (Demsetz and Lehn 1985), which, in turn, may increase the information asymmetry problem between directors and outside investors (minority shareholders and creditors). Therefore, it is likely that the firm with higher director ownership can have a higher cost of borrowing and a negative impact on profitability. It can be argued that director ownership may worsen the agency problem, as the outsider and insider can have conflicting interests (Demsetz and Lehn 1985). The second hypothesis is as follows:

Hypothesis 2. There is a positive and statistically significant association between director ownership and firms' COC.

A limited number of studies only provide evidence on the relationship between institutional ownership and one component of the cost of capital. Institutional investors usually have a higher monitoring power, and it has been suggested that they can play a crucial role by forcing managers to make decisions in the best interest of shareholders (Shleifer and Vishny 1986). Crutchley et al. (1999) argue that institutional investors can have an impact on firms' capital structure.

Theoretically, monitoring can be beneficial to reduce the agency cost by minimising the conflicts of directors and investors (Solomon et al. 2003; Jensen and Meckling 1979). Arguably, intuitional investors with a significant shareholding are proposed as important CG mechanism for three main reasons (Diamond and Verrecchia 1991; Donnelly and Mulcahy 2008). First, having a considerable portion of shareholding and voting power permits them to take necessary actions (Donnelly and Mulcahy 2008). 
Second, institutional investors have resources and capabilities to have more information than minority shareholders (Smith 1976). Third, with better knowledge and expertise, they can evaluate the firm's decisions and can interpret the disclosed information in annual reports (Chung et al. 2003; Bos and Donker 2004; Khan 2016; Elshandidy and Neri 2015). Thus, it is expected that institutional ownership can increase firm value by decreasing the firm's cost of capital. Therefore, the following is predicted:

Hypothesis 3. Institutional ownership and firms' COC are significantly negatively associated.

From the resources dependence theory perspective, firms with higher government ownership can easily access financing from the government (Eng and Mak 2003). Arguably, firms may take the benefit of higher government cost of capital and, in turn, may increase the firm value. Similarly, (Siebels and Knyphausen-Aufseß 2012) argue that government ownership may not affect the managers due to their aligned interests with other corporate owners. Individually, executives may strive for improvement in the firm performance to improve and protect their reputation (Conyon and He 2011). In contrast, (Eng and Mak 2003) argue that higher state-owned firms may origin the agency problem. In this regard, government ownership may cause intervention in firms' operations, which may bring about weak corporate governance practices (Konijn et al. 2011). For example, the government may employ directors and a CEO irrespective of qualification (Cornett et al. 2010; Tsamenyi et al. 2007). Hence, we expect the following:

Hypothesis 4. Firms' COC and government ownership are significantly and negatively associated.

The dominance of majority shareholders in publically traded firms demonstrates the willingness to accept risk by minority shareholders. (Bozec et al. 2014) argue that such risks are accepted by minority shareholders based on compensation. High-risk results in higher cost of capital for firms. Arguably, a higher cost of capital means a higher rate of return for investors that can be a form of compensation to them. Hence, it can be argued that block ownership is expected to have a more direct link with the cost of capital rather than financial performance and firm value, mainly as value is not only affected by risk but also by the firm's growth opportunities (Hail and Leuz 2006).

Empirical studies report mixed evidence in the relationship of block holders and firm-level cost of capital. For instance, Bozec et al. (2014) report significant empirical evidence of a positive correlation between excess control and the weighted average cost of capital. Similarly, Elston and Rondi (2007) report empirical evidence that concentrated inside ownership is significantly and positively associated with the firm cost of capital for Italian firms while having no significant relationship between the variables for German firms. In contrast, Pham et al. (2012) report significant empirical evidence of a negative relationship between concentrated ownership and the weighted average cost of capital.

Hypothesis 5. There is a statistically significant association between block ownership and firms' COC.

A firm's choice of issuing debt or equity to finance their activities can be affected by foreign investors. Theoretically, information asymmetry is relatively higher among foreign investors because of language and distance (Huafang and Jianguo 2007). Higher foreign ownership may lead to debt financing as a governance mechanism; thus, it may force firms to issue debt over equity (Phung and Le 2013). Additionally, firms may prefer debt rather than equity as they may take advantage of foreign investors' relationship and reputation to have easy access to international capital markets, which will usually provide a lower cost of borrowing and, thus, lower cost of capital. As a result, it the following can be argued:

Hypothesis 6. Firms' COC and foreign ownership are significantly and negatively associated. 


\section{Data and Research Design}

\subsection{Data Sample and Summary Statistics}

The sample used in analysing the CG compliance level (PCGI) and its impact on the cost of capital (COC) was made up of the Karachi Stock Exchange (KSE) listed firms. The majority of KSE listed firm's annual reports became publicly available in 2003 with required CG information after the issuance of Pakistani CG code in 2002. This makes it possible to gather data from 2003, when the code was effectively implemented, and firms started to publish their annual reports. The sample ends in 2013, as it was the most recent year with available data at the time of data's being manually collected.

To be included in the sample of this study, a firm has to meet two conditions. First, the firms' eleven-year annual reports from 2003 to 2013, inclusive, must be available. Second, its corresponding eleven-year financial and stock market information had to be available. In this study, the financial industry is not included in the final sample for three main reasons. First, financial firms have a different capital structure than those of nonfinancial firms, which may have an impact on firm value (Lim and Wang 2007; Ali Shah and Butt 2009). Second, financial firms have been suggested to be heavily regulated. In the case of Pakistan, financial firms are required to comply with more regulations than their industrial counterparts do. We ended up with 160 firms for the period 2003 to 2013 and with 1760 firm-year observations.

There are three types of data being used in this study, namely (i) corporate governance variables, (ii) financial variables, and (ii) Stock Market variables. First, using a content analysis approach, corporate governance variables were manually collected from the annual reports of the sampled firms. These annual reports were collected from different sources: Rest of World Filings of the Perfect Information Database, the companies' website, and the KSE website. Firms' annual reports that were not available in the above sources were obtained from the SECP head office in Islamabad, Pakistan. Second, the data on financial variables of 130 firms were collected from Datastream, while the data for the remaining 30 firms were collected from Balance Sheet Analyses of State Bank of Pakistan's publication. Sampled firms' monthly stock prices, Government of Pakistan T-Bill rates, and Market indices variables constitute the third type of data used in this study, which were collected from Datastream. Missing or insufficient data related to the Company's monthly stock prices, Government of Pakistan T-Bill rates, and market indices data were collected from the website of the business recorder.

Table 1 presents summary statistics. The minimum of PCGI is 0.00 , and the maximum is 97.18 , while the mean score of the index is $\mathbf{5 4 . 2 3}$ for 1760 firm-year observations. There is a relatively large variation in the CG compliance among Pakistani listed firms, as shown by a standard deviation of 33.57. The findings are in line with the previous corporate governance literature (e.g., Ntim et al. 2012; Henry 2008), indicating that corporate governance standards improve over time. The mean of director ownership is $20.88 \%$, with a minimum of $0 \%$ and a maximum of $98 \%$. The average of director ownership is relatively high among Pakistani listed firms ${ }^{1}$ (Samaha et al. 2012; Henry 2008).

1 Samaha et al. (2012) report 9\% of director ownership in Egyptian firms. Similarly, Henry (2008) reports 6\% of director ownership in Australian firms. 
Table 1. Summary statistics.

\begin{tabular}{ccccccc}
\hline Variables & Observations & Mean & Median & SD & Maximum & Minimum \\
\hline COC & 1760 & 0.209 & 0.156 & 0.276 & 0.976 & -0.470 \\
COD & 1760 & 0.196 & 0.072 & 0.258 & 0.700 & 0.000 \\
COE & 1760 & 0.255 & 0.212 & 0.303 & 0.932 & -0.307 \\
& \multicolumn{7}{c}{ Panel B: Independent variables } \\
PCGI & 1760 & 54.230 & 74.648 & 33.572 & 97.183 & 0.000 \\
DOWNP & 1760 & 20.879 & 9.001 & 24.811 & 98.371 & 0.000 \\
IOWNP & 1760 & 10.699 & 5.543 & 14.674 & 95.471 & 0.000 \\
GOWNP & 1760 & 6.397 & 1.741 & 12.564 & 95.023 & 0.000 \\
BOWNP & 1760 & 55.451 & 55.220 & 26.727 & 99.806 & 0.000 \\
FOWNP & 1760 & 9.967 & 0.000 & 21.624 & 93.187 & 0.000 \\
BIG4 & 1760 & 0.551 & 1.000 & 0.498 & 1.000 & 0.000 \\
BSZ & 1760 & 8.220 & 8.000 & 1.683 & 17.000 & 6.000 \\
BGEN & 1760 & 11.398 & 0 & 23.376 & 1 & 0 \\
& & \multicolumn{7}{c}{ Panel C: Control variables } & & \\
LTA & 1760 & 16.017 & 15.641 & 2.082 & 21.304 & 12.636 \\
ROE & 1760 & 0.146 & 0.103 & 0.225 & 0.692 & -0.212 \\
SALESG & 1760 & 0.163 & 0.127 & 0.388 & 1.655 & -0.728 \\
LVG & 1760 & 30.605 & 25.853 & 30.491 & 147.877 & 0.000 \\
$\beta$ & 1760 & 0.590 & 0.567 & 0.564 & 2.106 & -0.529 \\
\hline
\end{tabular}

Notes: This table reports the summary statistics for a sample period of 160 Pakistani firms from 2003 to 2013. Appendix A presents the definitions of variables. COC denotes the cost of capital, COD denotes the cost of debt, COE denotes the cost of equity, PCGI denotes the Pakistani Corporate Governance Index, DOWNP represents director ownership, IOWNP represents institutional ownership, GOWNP represents government ownership, BOWNP represents block ownership, FOWNP represents foreign ownership, BIG4 represents the audit firm size, BSZ represents the size of the board of directors, BGEN represents board diversity on the basis of gender, BNAT represents board diversity on the basis of nationality, LTA represents firm size as the log of total assets, ROE represents return on equity as a measure of profitability, SALESG represents growth opportunities, LVG represents leverage, and $\beta$ represents Beta-a measure of risk.

The mean of institutional ownership is $10.70 \%$, with a minimum of 0 and a maximum of $95 \%$, revealing that there is a substantial variation in this variable. However, this average institutional ownership is consistent with some of the previous studies. For instance, Aggarwal et al. (2011) report average institutional ownership of $8 \%, 8 \%$, and $9 \%$ in Greece, Hong Kong, and New Zealand, respectively. On the other hand, Chung and Zhang (2011) report over 50\% of institutional ownership among US firms.

Concerning government ownership, the average is $6.39 \%$ with a minimum of 0 and a maximum of $95 \%$, revealing that the Pakistani government relatively holds a high percentage of firms' share and is expected to have an impact on the willingness of firms to comply with CG provisions. The average of block ownership is $55.45 \%$, with a minimum of 0 and a maximum of $99.80 \%$, revealing a higher level of ownership concentration among Pakistani listed firms. The high level of block ownership may suggest a low CG compliance and disclosure, as it is expected that the market for control may not be working well, as compared with a low concentration of ownership.

Regarding foreign ownership, its mean is $9.97 \%$, with a minimum of 0 and a maximum of $93 \%$, with a standard deviation of $21.62 \%$. This may suggest that the presence of foreign ownership can have an important role in improving the CG standards among Pakistani listed firms. This is supported by a correlation coefficient. Appendix $C$ shows the correlation matrix in more detail. 


\subsection{Empirical Model}

The impact of the level of CG compliance and its relationship with COC for Pakistani listed firms is estimated by the following ordinary least square model:

$$
\begin{aligned}
\text { COC }_{i t}= & \alpha_{0}+\beta_{1} \text { PCGI }_{i t}+\beta_{2} \text { DOWNP }_{i t}+\beta_{3} \text { IOWNP }_{i t}+\beta_{4} \text { GOWNP }_{i t} \\
& +\beta_{5} \text { BOWNP }_{i t}+\beta_{6} \text { FOWNP }_{i t}+\beta_{7} \text { BIG }_{i t}+\beta_{8} \text { BSZ }_{i t} \\
& +\beta_{9} \text { BGEN }_{i t}+\sum_{i=1}^{n} \beta_{i} \text { CONTROLS }_{i t}+\varepsilon_{i t}
\end{aligned}
$$

where $i$ and $t$ subscript represents firm and time, respectively. COC is the cost of capital calculated by the weighted average cost of capital. PCGI is the Pakistani Corporate Governance Index. DOWNP is the percentage of shares owned by directors, and IOWNP is the percentage of shares owned by institutions. GOWNP indicates the percentage of shares owned by the government. BOWNP represents the percentage of shares owned by shareholders with at least $5 \%$. FOWNP accounts for the percentage of shares owned by the foreigner.

A set of control variables includes firm size (LTA), profitability (ROE), sales growth (SALESG), leverage (LEVG), capital expenditure (CETA), and Beta $(\beta)$. Beta $(\beta)$ measures the Beta of the firm by using a regression of stock return to market returns. Industry and year fixed effects are included in all models; $\varepsilon$ is the error term.

\section{Empirical Results}

\subsection{Main Findings}

In this study, the impact of the level of corporate governance compliance and its relationship with the cost of capital for Pakistani listed firms were investigated. As shown in Table 2, we find that the coefficient on PCGI is negative and statistically significant at $5 \%$ level, suggesting that firms with a high level of corporate governance standards have a lower cost of capital. Our finding is consistent with our first hypothesis. In the case of most developing countries, when firms have controlling shareholders (see Claessen et al. 2000; Faccio and Lang 2002), corporate governance mitigates agency problems between insider shareholders and outside investors, including both creditors and minority shareholders. Similarly, good corporate governance practices in Pakistan are intended to safeguard minority shareholders and creditors among other outside investors against the expropriation of controlling shareholders.

Table 2 shows the findings of the influence of ownership variables on firms' cost of capital. First, the coefficient on director ownership is positive and statistically significant, suggesting that firms with a high level of director ownership have a higher cost of capital. Our finding is in line with the second hypothesis, and the prediction of agency theory a higher level of director ownership may worsen agency problems (Demsetz and Lehn 1985). In a similar vein, it has been suggested that higher director shareholdings may make a firm more vulnerable to collusion between directors and firm management (Vafeas and Theodorou 1998; Konijn et al. 2011). In this regard, Bennedsen and Wolfenzon (2000) argue that one of the three ways by which multiple block-holders can influence firm value is that they can use their power to form a coalition to expropriate value at the expense of other shareholders.

Second, the coefficient on institutional ownership on the cost of capital is positive and statistically insignificant, meaning that the percentage of institutional ownership has no explanatory power in explaining the variation in the firm-level cost of capital. This is contrary to the formulated third hypothesis. Theoretically, the relationship between institutional ownership and cost of capital being negative can be useful, as monitoring can be beneficial in reducing the conflicts of interest between investors and directors (Jensen and Meckling 1979; Solomon et al. 2003). However, the current study does not lend empirical support to the CG literature in regard to Pakistan (e.g., Bhojraj and Sengupta 2003; Piot and Missonier-Piera 2009), and it documents a negative relationship between institutional ownership and firm-level cost of capital. 
Table 2. The ordinary least squares (OLS) regression of CG and COC.

\begin{tabular}{|c|c|c|c|c|}
\hline \multicolumn{5}{|c|}{ Dependent Variable: COC } \\
\hline Independent Variables & Expected Sign & Coefficient & SE & $t$-Statistic \\
\hline \multicolumn{5}{|c|}{ Panel A: CG variables } \\
\hline PCGI & - & $-0.00026^{* *}$ & 0.000108 & -2.36741 \\
\hline DOWNP & + & $0.000448^{* *}$ & 0.000189 & 2.378413 \\
\hline IOWNP & - & 0.00011 & 0.000113 & 0.96854 \\
\hline GOWNP & - & 0.000242 & 0.000219 & 1.10389 \\
\hline BOWNP & $+/-$ & $-0.00017^{* * *}$ & 0.000487 & -3.3948 \\
\hline FOWNP & - & $0.000782 * * *$ & 0.000161 & 4.871608 \\
\hline BIG4 & - & -0.00039 & 0.00646 & -0.0599 \\
\hline BSZ & - & 0.002998 & 0.001825 & 1.642575 \\
\hline BGEN & - & $0.011861^{* *}$ & 0.005159 & 2.29886 \\
\hline \multicolumn{5}{|c|}{ Panel B: Control variables } \\
\hline LTA & & $-0.01866^{* * *}$ & 0.004099 & -4.5532 \\
\hline ROE & & $-0.00052 *$ & 0.000284 & -1.83358 \\
\hline SALESG & & -0.00168 & 0.005707 & -0.29502 \\
\hline LVG & & $-0.0007 * * *$ & 0.000166 & -4.23521 \\
\hline$\beta$ & & $0.152732 * *$ & 0.06078 & 2.512878 \\
\hline Industry fixed effects & & Yes & & \\
\hline Year fixed effects & & Yes & & \\
\hline Constant & & $0.493347^{* * *}$ & 0.037561 & 13.13452 \\
\hline Adjusted R-square & & 0.540825 & \multicolumn{2}{|c|}{ Sample: 20032013} \\
\hline F-statistic & & 60.19378 & \multicolumn{2}{|c|}{ Cross-sections included: 160} \\
\hline Prob(F-statistic) & & 0.00000 & Total panel (ba & servations: 1760 \\
\hline
\end{tabular}

Notes: Variables are defined as follows. Cost of capital (COC), Pakistani Corporate Governance Index (PCGI), director ownership (DOWNP), institutional ownership (IOWNP), government ownership (GOWNP), block ownership (BOWNP), foreign ownership (FOWNP), audit firm size (BIG4), size of the board of directors (BSZ), board diversity on the basis of Gender (BGEN), firm size as log of total assets (LTA), profitability (ROE), growth opportunities (SALESG), leverage (LVG) and systematic risk ( $\beta$ ). Parameter estimates were obtained by OLS estimation (panel least squares). The year 2003 and Auto industry were excluded from the analysis in order to avoid the dummy variable trap. The asterisks ***, and ${ }^{* * *}$ denote the $10 \%, 5 \%$, and $1 \%$ level of significance, respectively.

Third, the coefficient on government ownership is positive and statistically insignificant, suggesting that there is no statistically significant association between government ownership and firms' COC. This finding shows that the level of government ownership has no explanatory power in explaining the variation in firm-level COC. Theoretically, this positive relationship between government ownership and COC is consistent with the prediction of agency theory. Eng and Mak (2003) argue that higher government ownership may cause agency problems where government ownership may lead to intervention in firms' operations, which may result in poor corporate governance practices (Konijn et al. 2011; Elshandidy and Neri 2015). For instance, the government may appoint the CEO and directors regardless of experience and qualification (Tsamenyi et al. 2007; Cornett et al. 2010).

Fourth, unlike the institutional and government ownership, the coefficient on block ownership is negative and statistically significant at $1 \%$ level, suggesting that there is a relationship between the block ownership and firm-level cost of capital. This shows that Pakistani firms with a higher level of block ownership have a lower cost of capital than those firms with a smaller percentage of block ownership. This is consistent with the prediction of agency theory in which the dominance of majority shareholders in publicly traded firms demonstrates that minority shareholders have the risk of expropriation. Bozec et al. (2014) argue that minority shareholders can accept such a risk as long as they are compensated. Empirically, this finding is in line with the previous literature (e.g., Pham et al. 2012) that provides empirical evidence of a negative relationship between ownership concentrations on the firm-level weighted average cost of capital.

Finally, the coefficient on foreign ownership is positive and statistically significant at the $1 \%$ level, indicating that there is a statistically significant and positive relationship between foreign ownership and firm-level cost of capital, inconsistent with the sixth hypothesis. This finding shows that Pakistani 
firms with a higher level of foreign investors have a higher cost of capital than those with less or no foreign investors. Theoretically, this positive relationship between foreign ownership and the cost of capital is consistent with the prediction of information asymmetry. This issue is relatively higher among foreign investors because of language and distance obstacles (Huafang and Jianguo 2007), which may lead to a higher cost of capital. Empirically, the finding of this positive relationship between foreign ownership with firm-level COC is in line with the prior literature (e.g., Boubakri et al. 2016).

\subsection{Unweighted Index Versus Weighted Index}

The current study responds to the literature in order to address the possibility that the main findings may be sensitive to the type of corporate governance index. Hence, a weighted corporate governance index instead of an unweighted corporate governance index is employed by assigning $20 \%$ weight to each sub-index of PCGI, whereas the unweighted corporate governance index has different weights assigned to each sub-index ${ }^{2}$. This procedure is line with prior studies (e.g., Beiner et al. 2006; Ntim et al. 2012) that used the same method to test whether their main findings are sensitive to the weighted corporate governance index (WPCGI) or not. Therefore, the PCGI in Equation (1) is replaced by the WPCGI. Table 3 shows a comparison for results using the unweighted index versus those using the weighted index.

2 The corporate governance index that is used in the current study to measure corporate governance compliance and disclosure among Pakistani listed firms consists of 70 corporate governance provisions divided into five sub-indices, which are equally weighted, but the number of corporate governance provisions are different in the five sub-indices and leads to different weights being assigned to each sub-index. 
Table 3. Results based on weighted CG index.

\begin{tabular}{|c|c|c|c|c|c|}
\hline \multicolumn{6}{|c|}{ Dependent Variable: COC } \\
\hline & & \multicolumn{2}{|c|}{ Unweighted Index } & \multicolumn{2}{|c|}{ Weighted Index } \\
\hline $\begin{array}{l}\text { Independent } \\
\text { Variable }\end{array}$ & $\begin{array}{l}\text { Expected } \\
\text { Sign }\end{array}$ & Coefficient & $t$-Statistic & Coefficient & $t$-Statistic \\
\hline \multicolumn{6}{|c|}{ Panel A: CG variables } \\
\hline PCGI & - & $-0.000256^{* *}$ & -2.367414 & $-\underset{* * *}{-0.000285}$ & -2.692242 \\
\hline DOWNP & + & $0.000448^{* *}$ & 2.378413 & $0.000453^{* *}$ & 2.409312 \\
\hline IOWNP & - & 0.000110 & 0.968540 & 0.000111 & 0.990667 \\
\hline GOWNP & - & 0.000242 & 1.103890 & 0.000253 & 1.140036 \\
\hline BOWNP & $+/-$ & $-0.000165^{* * *}$ & -3.394800 & $-\underset{* * *}{0.000169}$ & -3.466370 \\
\hline FOWNP & - & $0.000782^{* * *}$ & 4.871608 & $0.000787^{* * *}$ & 4.904898 \\
\hline BIG4 & - & -0.000387 & -0.059896 & -0.000282 & -0.043382 \\
\hline BSZ & - & 0.002998 & 1.642575 & 0.003034 * & 1.659411 \\
\hline BGEN & - & $0.011861^{* *}$ & 2.298860 & $0.011793^{* *}$ & 2.280540 \\
\hline \multicolumn{6}{|c|}{ Panel B: Control variables } \\
\hline LTA & & $-0.018664^{* * *}$ & -4.553196 & $\underset{* * *}{-0.018612}$ & -4.569124 \\
\hline ROE & & $-0.000520 *$ & -1.833582 & $-0.000519 *$ & -1.825441 \\
\hline SALESG & & -0.001684 & -0.295017 & -0.001598 & -0.280165 \\
\hline LVG & & $-0.000704^{* * *}$ & -4.235213 & $-\underset{* * *}{0.000706}$ & -4.250991 \\
\hline B & & $0.152732 *$ & 2.512878 & $0.152671^{* *}$ & 2.514698 \\
\hline $\begin{array}{l}\text { Industry fixed } \\
\text { effects }\end{array}$ & & \multicolumn{2}{|l|}{ Yes } & & \\
\hline $\begin{array}{l}\text { Year fixed } \\
\text { effects }\end{array}$ & & \multicolumn{2}{|l|}{ Yes } & & \\
\hline Constant & & $0.493347^{* * *}$ & 13.13452 & $0.493092^{* * *}$ & 13.17160 \\
\hline \multicolumn{2}{|c|}{ Adjusted R-square } & \multicolumn{2}{|c|}{0.540825} & \multicolumn{2}{|c|}{0.550872} \\
\hline \multicolumn{2}{|c|}{ F-statistic } & \multicolumn{2}{|c|}{$60.19378^{* * *}$} & \multicolumn{2}{|c|}{$60.41580^{* * *}$} \\
\hline \multicolumn{2}{|c|}{ Balanced panel observations } & \multicolumn{2}{|c|}{1760} & \multicolumn{2}{|c|}{1760} \\
\hline
\end{tabular}

Notes: Variables are defined as follows. Cost of capital (COC), Pakistani Corporate Governance Index (PCGI), director ownership (DOWNP), institutional ownership (IOWNP), government ownership (GOWNP), block ownership (BOWNP), foreign ownership (FOWNP), audit firm size (BIG4), size of the board of directors (BSZ), board diversity on the basis of gender (BGEN), firm size as log of total assets (LTA), profitability (ROE), growth opportunities (SALESG), leverage (LVG) and systematic risk ( $\beta$ ). Parameter estimates were obtained by OLS estimation (panel least squares). The year 2003 and Auto industry has been excluded from the analysis in order to avoid the dummy variable trap. The asterisks ***, and ${ }^{* * *}$ denote the $10 \%, 5 \%$, and $1 \%$ level of significance, respectively.

Adjusted R-square is 0.540825 for unweighted index and 0.550872 for weighted index, suggesting that $54 \%$ and $55 \%$ variability in PCGI and WPCGI, are jointly explained by independent variables in Equation (1). Similarly, the F-statistic is 60.19378, using unweighted index, and 60.41580, using the weighted index, and both are statistically significant at $1 \%$ level. This suggests that both analyses are appropriate, and all the parameters in the analyses are jointly significant. Generally, the findings of both analyses are similar, as both predict the same sign of coefficient, magnitude of coefficient, and level of significance, either using PCGI or WPCGI.

\subsection{Robustness Tests}

The current study employs alternative proxies for the cost of capital in order to account for the possibility that the main findings are sensitive to different proxies. In particular, and in line with past studies (e.g., Pham et al. 2012), the cost of equity and cost of debt is used as an alternative cost of capitals' measurement. The cost of debt is considered for the cost of selecting debt covenants; therefore, it signals credit risk and agency problems (Kim 2018; Elshandidy and Neri 2015). Tables 4 and 5 
report results for the cost of equity and cost of debt, respectively. We find consistent results with our main findings.

Table 4. Results based on cost of equity.

\begin{tabular}{|c|c|c|c|c|c|}
\hline \multicolumn{6}{|c|}{ Dependent Variable: COC/COE } \\
\hline & & \multicolumn{2}{|c|}{ Dependent Variable: COC } & \multicolumn{2}{|c|}{ Dependent Variable: COE } \\
\hline $\begin{array}{l}\text { Independent } \\
\text { Variable }\end{array}$ & $\begin{array}{l}\text { Expected } \\
\text { Sign }\end{array}$ & Coefficient & $t$-Statistic & Coefficient & $t$-Statistic \\
\hline \multicolumn{6}{|c|}{ Panel A: CG variables } \\
\hline PCGI & - & $-0.000256^{* *}$ & -2.367414 & $-0.000158 * *$ & -2.204032 \\
\hline DOWNP & + & $0.000448^{* *}$ & 2.378413 & 0.000176 & 1.101021 \\
\hline IOWNP & - & 0.000110 & 0.968540 & 0.000121 & 0.082011 \\
\hline GOWNP & - & 0.000242 & 1.103890 & 0.000146 & 0.605721 \\
\hline BOWNP & $+/-$ & $-0.000165^{* * *}$ & -3.394800 & -0.000101 & -1.558801 \\
\hline FOWNP & - & $0.000782^{* * *}$ & 4.871608 & $0.000411^{* * *}$ & 2.638581 \\
\hline BIG4 & - & -0.000387 & -0.059896 & 0.006483 & 0.905017 \\
\hline BSZ & - & 0.002998 & 1.642575 & 0.004159 & 1.500352 \\
\hline BGEN & - & $0.011861 * *$ & 2.298860 & 0.007951 & 1.085436 \\
\hline \multicolumn{6}{|c|}{ Panel B: Control variables } \\
\hline LTA & & $-0.018664^{* * *}$ & -4.553196 & 0.001458 & 0.795485 \\
\hline ROE & & $-0.000520 *$ & -1.833582 & $-0.000397^{* *}$ & -2.385347 \\
\hline SALESG & & -0.001684 & -0.295017 & -0.006968 & -0.894314 \\
\hline LVG & & $-0.000704^{* * *}$ & -4.235213 & 0.000589 & 0.881462 \\
\hline$\beta$ & & $0.152732 *$ & 2.512878 & $0.262360 * * *$ & 2.959989 \\
\hline $\begin{array}{l}\text { Industry fixed } \\
\text { effects }\end{array}$ & & \multicolumn{2}{|l|}{ Yes } & & \\
\hline $\begin{array}{l}\text { Year fixed } \\
\text { effects }\end{array}$ & & \multicolumn{2}{|l|}{ Yes } & & \\
\hline Constant & & $0.493347^{* * *}$ & 13.13452 & $0.217037^{* * *}$ & 3.344781 \\
\hline \multicolumn{2}{|c|}{ Adjusted R-square } & \multicolumn{2}{|c|}{0.540825} & \multicolumn{2}{|c|}{0.744496} \\
\hline \multicolumn{2}{|c|}{ F-statistic } & \multicolumn{2}{|c|}{$60.19378^{* * *}$} & \multicolumn{2}{|c|}{$147.4412^{* * *}$} \\
\hline \multicolumn{2}{|c|}{ Balanced panel observations } & \multicolumn{2}{|c|}{1760} & \multicolumn{2}{|c|}{1760} \\
\hline
\end{tabular}

Notes: Variables are defined as follows. Cost of capital (COC), Pakistani Corporate Governance Index (PCGI), director ownership (DOWNP), institutional ownership (IOWNP), government ownership (GOWNP), block ownership (BOWNP), foreign ownership (FOWNP), audit firm size (BIG4), size of the board of directors (BSZ), board diversity on the basis of gender (BGEN), firm size as log of total assets (LTA), profitability (ROE), growth opportunities (SALESG), leverage (LVG), and systematic risk ( $\beta$ ). Parameter estimates were obtained by OLS estimation (panel least squares). The year 2003 and Auto industry were excluded from the analysis in order to avoid the dummy variable trap. The asterisks ${ }^{*}, * *$, and ${ }^{* * *}$ denote the $10 \%, 5 \%$, and $1 \%$ level of significance, respectively.

Table 5. Results based on cost of debt.

\begin{tabular}{|c|c|c|c|c|c|}
\hline \multicolumn{6}{|c|}{ Dependent Variable: COC/COD } \\
\hline & & \multicolumn{2}{|c|}{ Dependent Variable: COC } & \multicolumn{2}{|c|}{ Dependent Variable: COD } \\
\hline $\begin{array}{l}\text { Independent } \\
\text { Variable }\end{array}$ & $\begin{array}{l}\text { Expected } \\
\text { Sign }\end{array}$ & Coefficient & $t$-Statistic & Coefficient & $t$-Statistic \\
\hline \multicolumn{6}{|c|}{ Panel A: CG variables } \\
\hline PCGI & - & $-0.000256^{* *}$ & -2.367414 & $-0.000556^{* * *}$ & -3.764441 \\
\hline DOWNP & + & $0.000448^{* *}$ & 2.378413 & $0.000150 * *$ & 2.021592 \\
\hline IOWNP & - & 0.000110 & 0.968540 & $4.21 \times 10^{-5}$ & 0.209547 \\
\hline GOWNP & - & 0.000242 & 1.103890 & -0.000204 & -1.365303 \\
\hline BOWNP & $+/-$ & $-0.000165^{* * *}$ & -3.394800 & $-0.000258^{* * *}$ & -7.090828 \\
\hline FOWNP & - & $0.000782 * * *$ & 4.871608 & $0.000926^{* * *}$ & 5.473368 \\
\hline BIG4 & - & -0.000387 & -0.059896 & $-0.016931^{* * *}$ & -3.138824 \\
\hline BSZ & - & 0.002998 & 1.642575 & -0.001615 & -0.854725 \\
\hline BGEN & - & $0.011861 * *$ & 2.298860 & 0.006309 & 1.638559 \\
\hline
\end{tabular}


Table 5. Cont.

\begin{tabular}{|c|c|c|c|c|c|}
\hline \multicolumn{6}{|c|}{ Dependent Variable: COC/COD } \\
\hline & & \multicolumn{2}{|c|}{ Dependent Variable: COC } & \multicolumn{2}{|c|}{ Dependent Variable: COD } \\
\hline $\begin{array}{l}\text { Independent } \\
\text { Variable }\end{array}$ & $\begin{array}{l}\text { Expected } \\
\text { Sign }\end{array}$ & Coefficient & $t$-Statistic & Coefficient & $t$-Statistic \\
\hline \multicolumn{6}{|c|}{ Panel B: Control variables } \\
\hline LTA & & $-0.018664^{* * *}$ & -4.553196 & $-0.029582 * * *$ & -8.405904 \\
\hline ROE & & $-0.000520 *$ & -1.833582 & $-0.000696^{* * *}$ & -2.721204 \\
\hline SALESG & & -0.001684 & -0.295017 & -0.006232 & -1.136623 \\
\hline LVG & & $-0.000704^{* * *}$ & -4.235213 & $-0.000348^{* * *}$ & -9.934225 \\
\hline$\beta$ & & $0.152732 *$ & 2.512878 & 0.005018 & 1.022498 \\
\hline $\begin{array}{l}\text { Industry fixed } \\
\text { effects }\end{array}$ & & \multicolumn{2}{|l|}{ Yes } & & \\
\hline $\begin{array}{l}\text { Year fixed } \\
\text { effects }\end{array}$ & & \multicolumn{2}{|l|}{ Yes } & & \\
\hline Constant & & $0.493347^{* * *}$ & 13.13452 & $0.756528 * * *$ & 9.673746 \\
\hline \multicolumn{2}{|c|}{ Adjusted R-square } & \multicolumn{2}{|c|}{0.540825} & \multicolumn{2}{|c|}{0.270132} \\
\hline \multicolumn{2}{|c|}{ F-statistic } & \multicolumn{2}{|c|}{$60.19378^{* * *}$} & \multicolumn{2}{|c|}{$19.60072^{* * *}$} \\
\hline Balanced par & servations & \multicolumn{2}{|c|}{1760} & \multicolumn{2}{|c|}{1760} \\
\hline
\end{tabular}

Notes: Variables are defined as follows. Cost of capital (COC), Pakistani Corporate Governance Index (PCGI), director ownership (DOWNP), institutional ownership (IOWNP), government ownership (GOWNP), block ownership (BOWNP), foreign ownership (FOWNP), audit firm size (BIG4), size of the board of directors (BSZ), board diversity on the basis of gender (BGEN), firm size as log of total assets (LTA), profitability (ROE), growth opportunities (SALESG), leverage (LVG), and systematic risk ( $\beta$ ). Parameter estimates were obtained by OLS estimation (panel least squares). The year 2003 and Auto industry were excluded from the analysis in order to avoid the dummy variable trap. The asterisks ${ }^{*}, * *$, and ${ }^{* * *}$ denote the $10 \%, 5 \%$, and $1 \%$ level of significance, respectively.

We further employed lagged structure to examine the extent to which the main findings were affected by the endogeneity problem. Table 6 presents the results. Generally, the findings of both analyses are similar, as both analyses predict almost the same sign and magnitude of coefficient with the level of significance.

Table 6. Results based on lagged structure.

\begin{tabular}{|c|c|c|c|c|c|}
\hline \multicolumn{6}{|c|}{ Dependent Variable: COC } \\
\hline & & \multicolumn{2}{|c|}{ Un-Lagged Structure } & \multicolumn{2}{|c|}{ Lagged Structure } \\
\hline $\begin{array}{l}\text { Independent } \\
\text { Variable }\end{array}$ & $\begin{array}{l}\text { Expected } \\
\text { Sign }\end{array}$ & Coefficient & $t$-Statistic & Coefficient & $t$-Statistic \\
\hline \multicolumn{6}{|c|}{ Panel A: CG variables } \\
\hline PCGI $(-1)$ & - & $-0.000256^{* *}$ & -2.367414 & $-0.000250 *$ & -1.838121 \\
\hline DOWNP $(-1)$ & + & $0.000448^{* *}$ & 2.378413 & $0.000496^{* * *}$ & 2.613038 \\
\hline $\operatorname{IOWNP}(-1)$ & - & 0.000110 & 0.968540 & $0.000270 *$ & 1.802866 \\
\hline GOWNP $(-1)$ & - & 0.000242 & 1.103890 & -0.000892 & -0.285109 \\
\hline BOWNP (-1) & $+/-$ & $-0.000165^{* * *}$ & -3.394800 & $-\underset{* * *}{0.000196}$ & -2.968802 \\
\hline FOWNP (-1) & - & $0.000782 * * *$ & 4.871608 & $0.000795^{* * *}$ & 4.081046 \\
\hline $\mathrm{BIG} 4(-1)$ & - & -0.000387 & -0.059896 & 0.001296 & 0.151817 \\
\hline $\mathrm{BSZ}(-1)$ & - & 0.002998 & 1.642575 & 0.002940 & 1.359421 \\
\hline BGEN $(-1)$ & - & $0.011861 * *$ & 2.298860 & 0.010384 & 1.204158 \\
\hline \multicolumn{6}{|c|}{ Panel B: Control variables } \\
\hline LTA $(-1)$ & & $-0.018664^{* * *}$ & -4.553196 & $-\underset{* * *}{0.018774}$ & -8.242142 \\
\hline $\operatorname{ROE}(-1)$ & & $-0.000520 *$ & -1.833582 & $-0.000559 *$ & -1.820631 \\
\hline SALESG $(-1)$ & & -0.001684 & -0.295017 & -0.001323 & -0.135539 \\
\hline
\end{tabular}


Table 6. Cont.

\begin{tabular}{|c|c|c|c|c|}
\hline \multicolumn{5}{|c|}{ Dependent Variable: COC } \\
\hline \multirow[b]{2}{*}{$\begin{array}{l}\text { Independent } \\
\text { Variable }\end{array}$} & \multicolumn{2}{|c|}{ Un-Lagged Structure } & \multicolumn{2}{|c|}{ Lagged Structure } \\
\hline & Coefficient & $t$-Statistic & Coefficient & $t$-Statistic \\
\hline $\operatorname{LVG}(-1)$ & $-0.000704^{* * *}$ & -4.235213 & $-\underset{* * *}{-0.000705}$ & -8.992319 \\
\hline $\mathrm{B}(-1)$ & $0.152732 *$ & 2.512878 & $0.152765^{* * *}$ & 19.22891 \\
\hline Industry fixed effects & Yes & & & \\
\hline Year fixed effects & Yes & & & \\
\hline Constant & $0.493347^{* * *}$ & 13.13452 & $0.496610^{* * *}$ & 12.83157 \\
\hline Adjusted R-square & \multicolumn{2}{|c|}{0.540825} & \multicolumn{2}{|c|}{0.540752} \\
\hline F-statistic & \multicolumn{2}{|c|}{$60.19378^{* * *}$} & \multicolumn{2}{|c|}{$58.53265 * * *$} \\
\hline Balanced panel observations & \multicolumn{2}{|c|}{1760} & \multicolumn{2}{|c|}{1600} \\
\hline
\end{tabular}

Notes: Variables are defined as follows. Cost of capital (COC), Pakistani Corporate Governance Index (PCGI), director ownership (DOWNP), institutional ownership (IOWNP), government ownership (GOWNP), block ownership (BOWNP), foreign ownership (FOWNP), audit firm size (BIG4), size of the board of directors (BSZ), board diversity on the basis of gender (BGEN), firm size as log of total assets (LTA), profitability (ROE), growth opportunities (SALESG), leverage (LVG), and systematic risk ( $\beta$ ). Parameter estimates were obtained by OLS estimation (panel least squares). The year 2003 and Auto industry were excluded from the analysis in order to avoid the dummy variable trap. The asterisks ${ }^{*}, * *$, and ${ }^{* *}$ denote the $10 \%, 5 \%$, and $1 \%$ level of significance, respectively.

\subsection{Two-Stage Least Squares Result}

After carrying out the Durbin-Wu-Hausman exogeneity investigation, the current study rejects the null hypothesis of no endogeneity as the coefficient on P-PCGI is statistically significant $(0.000)$ at $1 \%$ level of significance with PCGI. The finding of this investigation shows that the endogeneity problem exists. Therefore, following, the current study uses the Two Stage Least Square (2SLS) technique as robust to find out how far the findings are biased and inconsistent due to this problem.

2SLS is performed in two stages. In the first stage, the PCGI is regressed on four alternative CG variables, namely board diversity based on nationality, the number of non-executive directors on the board, the number of board of directors' meetings, and capital expenditure, besides, to controlling variables. The alternative CG variables' selection is based on literature (e.g., Ntim et al. 2012; Pham et al. 2012; Ntim and Soobaroyen 2013; Tariq and Abbas 2013). The equation below specifies this regression, where the predicted value of PCGI and residuals will be saved as P-PCGII and R-PCGI, respectively. The study accepts the P-PCGII as a valid instrumental variable as P-PCGII is significantly associated with PCGI and insignificantly related to R-PCGI. This decision is taken based on the correlation matrix that includes PCGI, P-PCGII, and R-PCGI.

$$
P C G I_{i t}=\alpha_{0}+\beta_{1} B N A T_{i t}+\beta_{2} N E X D_{i t}+\beta_{3} B M F_{i t}+\beta_{4} C E_{i t}+\sum_{i=1}^{n} \beta_{i} C O N T R O L S_{i t}+\varepsilon_{i t}
$$

where PCGI refers to the Pakistani CG index, and BNAT, NEXD, BFM, and CE are defined as board diversity based on nationality, the number of non-executive directors on the board, the number of board of directors' meetings, and capital expenditure, respectively. Control variables remain the same, as explained in Equation (2).

In the second stage, Equation (2) is re-estimated, using P-PCGII instead of PCGI, as follows:

$$
\begin{aligned}
\text { COC }_{i t}= & \alpha_{0}+\beta_{1} P-\text { PCGII }_{i t}+\beta_{2} \text { DOWNP }_{i t}+\beta_{3} \text { IOWNP }_{i t}+\beta_{4} \text { GOWNP }_{i t} \\
& +\beta_{5} \text { BOWNP }_{i t}+\beta_{6} \text { FOWNP }_{i t}+\beta_{7} \text { BIG }_{i t}+\beta_{8} \text { BSZ }_{i t} \\
& +\beta_{9} \text { BGEN }_{i t}+\sum_{i=1}^{n} \beta_{i} \text { CONTROLS } \\
\text { CON } & +\varepsilon_{i t}
\end{aligned}
$$


where all variables remain the same as in Equation (1), except the P-PCGII that is being used as an instrumental variable for the primary independent variable.

The findings of 2SLS (robust results) and OLS estimation (primary analysis) are presented in Table 7, simultaneously, in order to compare the results.

Table 7. Two-stage least-square result.

\begin{tabular}{|c|c|c|c|c|c|}
\hline \multicolumn{6}{|c|}{ Dependent Variable: COC } \\
\hline & & \multicolumn{2}{|c|}{ Ordinary Least Square } & \multicolumn{2}{|c|}{ 2SLS } \\
\hline $\begin{array}{c}\text { Independent } \\
\text { Variable }\end{array}$ & $\begin{array}{l}\text { Expected } \\
\text { Sign }\end{array}$ & Coefficient & $t$-Statistic & Coefficient & $t$-Statistic \\
\hline \multicolumn{6}{|c|}{ Panel A: CG variables } \\
\hline PCGI & - & $-0.000256^{* *}$ & -2.367414 & $-\underset{* *}{-0.003473}$ & -2.368299 \\
\hline DOWNP & + & $0.000448^{* *}$ & 2.378413 & $\underset{* * *}{0.000808}$ & 2.755872 \\
\hline IOWNP & - & 0.000110 & 0.968540 & 0.000451 & 1.036336 \\
\hline GOWNP & - & 0.000242 & 1.103890 & $0.001057 *$ & 1.668139 \\
\hline BOWNP & $+/-$ & $-0.000165^{* * *}$ & -3.394800 & $\underset{* * *}{-0.000312}$ & -2.802401 \\
\hline FOWNP & - & $0.000782^{* * *}$ & 4.871608 & $\underset{* * *}{0.001167}$ & 4.033018 \\
\hline BIG4 & - & -0.000387 & -0.059896 & 0.012895 & 0.909296 \\
\hline BSZ & - & 0.002998 & 1.642575 & -0.001324 & -0.341998 \\
\hline BGEN & - & $0.011861 * *$ & 2.298860 & -0.002020 & -0.148545 \\
\hline \multicolumn{6}{|c|}{ Panel B: Control variables } \\
\hline LTA & & $-0.018664^{* * *}$ & -4.553196 & $\underset{* * *}{-0.015608}$ & -3.683365 \\
\hline $\mathrm{ROE}$ & & $-0.000520 *$ & -1.833582 & $-\underset{* * *}{-0.001147}$ & -2.668026 \\
\hline SALESG & & -0.001684 & -0.295017 & -0.008931 & -0.574553 \\
\hline LVG & & $-0.000704^{* * *}$ & -4.235213 & $-\underset{* * *}{-0.000756}$ & -6.888064 \\
\hline$\beta$ & & $0.152732 *$ & 2.512878 & $\underset{* * *}{0.151077}$ & 13.68539 \\
\hline Industry fixed effe & & \multicolumn{2}{|l|}{ Yes } & & \\
\hline Year fixed effect & & \multicolumn{2}{|l|}{ Yes } & & \\
\hline Constant & & $0.493347^{* * *}$ & 13.13452 & $\underset{* * *}{0.565122}$ & 8.267790 \\
\hline \multicolumn{2}{|c|}{ Adjusted R-square } & \multicolumn{2}{|c|}{0.540825} & \multicolumn{2}{|c|}{0.264234} \\
\hline \multicolumn{2}{|c|}{ F-statistic } & \multicolumn{2}{|c|}{$60.19378^{* * *}$} & \multicolumn{2}{|c|}{$28.47540^{* * *}$} \\
\hline \multicolumn{2}{|c|}{ Balanced panel observations } & \multicolumn{2}{|c|}{1760} & \multicolumn{2}{|c|}{1760} \\
\hline
\end{tabular}

\footnotetext{
Notes: Variables are defined as follows. Cost of capital (COC), Pakistani Corporate Governance Index (PCGI), director ownership (DOWNP), institutional ownership (IOWNP), government ownership (GOWNP), block ownership (BOWNP), foreign ownership (FOWNP), audit firm size (BIG4), size of the board of directors (BSZ), board diversity on the basis of gender (BGEN), firm size as log of total assets (LTA), profitability (ROE), growth opportunities (SALESG), leverage (LVG), Two Stage Least Square (2SLS) and systematic risk ( $\beta)$. Parameter estimates were obtained by OLS estimation (panel least squares). The year 2003 and auto industry were excluded from the analysis in order to avoid the dummy variable trap. The asterisks ***, and ${ }^{* * *}$ denote the $10 \%, 5 \%$, and $1 \%$ level of significance, respectively.
}

The 2 stage least square (2SLS) finds a negative and significant association between PCGI and block ownership with the cost of capital. Similarly, a positive and significant nexus between director ownership and foreign ownership with the cost of capital is also consistent with the findings of the main analysis. However, minor sensitivity in the magnitude of coefficients and level of significance can be observed. For instance, director ownership is statistically significant at the $1 \%$ level, which was previously significant at the $5 \%$ level in the main analysis. Similarly, government ownership is 
significant at the 10\% level in the 2SLS analysis, whereas it was insignificant in the principal analysis. The findings of control variables in 2SLS are mainly similar to the primary analysis by using OLS.

\section{Conclusions}

This paper has sought to empirically ascertain whether Pakistani listed firms that comply with 2002 PCCG have improved firm value and lowered the cost of capital than those with less or no compliance. Specifically, using a sample of 160 Pakistani listed firms from 2003 to 2013, this study has examined the relationship between corporate governance structure and firm cost of capital. The level of compliance with PCGI and factors influencing the level of compliance and disclosure are also examined in this study.

We found a negative and statistically significant relationship between PCGI and the cost of capital. The evidence of a statistically significant PCGI and cost of capital relation implies that, on average, better governed Pakistani listed firms tend to be associated with a lower cost of capital than their poorly governed counterparts. Firms with a high level of director ownership have a higher cost of capital. The percentage of institutional ownership and government ownership do not explain the variation in the firm-level cost of capital. The coefficient of block ownership is negative and statistically significant at $1 \%$ level of significance, suggesting that Pakistani firms with a higher level of block ownership have a lower cost of capital than those firms with a smaller percentage of block ownership. As an emerging market, good corporate governance practices are particularly relevant to minimise corporate failure and assist firms to attract capital at a lower cost, as compared to other counterparts.

\section{Contributions and Policy Implications}

This study makes numerous contributions and extensions to the extant CG literature. For instance, this study offers for the first-time direct evidence on the effectiveness of CG reforms in Pakistan. Precisely, it provides detailed findings on the level of CG compliance and disclosure with the 2002 PCCG among listed firms. Similar to a limited number of prior studies in emerging markets, the introduction of 2002 PCCG facilitates uniformity and convergence of CG practices; the findings recommend that CG practices still differ largely among Pakistani listed firms over the eleven-year period examined. Additionally, to study the value-creating role of CG mechanisms by using an alternative approach (COC) to those which were used in the previous literature (ROA, ROE, and Tobin's Q) is another contribution to the literature, as there is a lack of empirical evidence on CG compliance and COC.

Similarly, the findings obtained from investigating the nexus between the CG standards and COC have several implications, and recommendations can be drawn from these findings. For instance, the findings of the current study demonstrate that there is a negative and significant association between the PCGI and block ownership with firm-level COC. This implies that, on average, better governed Pakistani listed firms tend to be associated with lower COC than their poorly governed counterparts. To an emerging market, good CG practices are particularly important, and, as such, practices may not only assist in minimising corporate failure but may also assist firms in attracting capital at a lower cost, as compared to their counterparts. Additionally, director ownership and foreign ownership are positively and significantly associated with firm-level of COC. This implies that firms can minimise director ownership to attract external financings at a lower cost. Hence, policymakers may encourage firms to further improve their CG structures in order to attract foreign investors. Finally, using a relatively old dataset could be a limitation of this study. However, in the CG studies, such time differences are somehow acceptable because of several reasons. For instance, the data collection is a tough job because of its nature of being hand-collected. Furthermore, as CG rules do not change quickly and also do not impact the firms' decisions so quickly, findings can still be generalised. However, the latest dataset with latest techniques and with additional statistical tests can be the future avenue of this area of research. Additionally, weighted index can also be used in this regard. 
Author Contributions: Conceptualization, M.Y.K. and A.J.; methodology, M.Y.K. and H.P.; validation, M.Y.K., A.J., and L.K.C.; formal analysis, M.Y.K. and H.P.; data collection, M.Y.K.; writing-original draft preparation, M.Y.K. and A.J.; writing-review and editing, L.K.C. and H.P.; supervision, H.P. All authors have read and agreed to the published version of the manuscript.

Funding: This research received no external funding.

Acknowledgments: The first author would like to thank Kwanku Opong and Marco Guidi for their advice and encouragement as the dissertation supervisors. The paper could not have been developed and improved if they were not supporting the first author as his supervisors, this paper is developed the idea from the 1st author's dissertation and improved with the participants of all authors. The authors, however, bear full responsibility for the article. The 4th author would like to say thank you to the Ho Chi Minh City Open University to support for this research (the presentation at the International Conference on Business and the partial funding to conduct this research).

Conflicts of Interest: The authors declare no conflict of interest.

\section{Appendix A}

Table A1. Summary of variables used in CG mechanisms and firm COC model.

\begin{tabular}{|c|c|}
\hline \multicolumn{2}{|r|}{ Dependent Variable } \\
\hline WACC & $\begin{array}{l}\text { Weighted average COC (WACC) is computed by using the after-tax cost of debt and cost of } \\
\text { equity by using weights of total debt and total equity to the total market capitalisation of } \\
\text { the firm. }\end{array}$ \\
\hline \multicolumn{2}{|c|}{ Independent Variables } \\
\hline PCGI & $\begin{array}{l}\text { Pakistani Corporate Governance Index (PCGI) consists of } 70 \text { provisions from Pakistani Code } \\
\text { of Corporate Governance, which takes a value of } 1 \text { if a particular CG provision is disclosed in } \\
\text { annual reports of company, and } 0 \text { otherwise; scaled to a value between } 0 \% \text { and } 100 \% \text {. }\end{array}$ \\
\hline DOWNP & Percentage of shares owned by directors to the total shares held by firm. \\
\hline IOWNP & Percentage of shares owned by institutions to the total shares held by firm. \\
\hline GOWNP & Percentage of shares owned by government to the total shares held by firm. \\
\hline BOWNP & $\begin{array}{l}\text { Percentage of shares owned by shareholders with at least } 5 \% \text { of total shares to the total } \\
\text { shares held by firm. }\end{array}$ \\
\hline FOWNP & Percentage of shares owned by foreigner to the total shares held by firm. \\
\hline BIG4 & 1 if firm is audited by one of the big-four ${ }^{3}$ audit firms, and 0 otherwise. \\
\hline BSZ & The total number of directors on the board of firm at the time of AGM. \\
\hline BGEN & 1 if firm has a female board member, and 0 otherwise. \\
\hline \multicolumn{2}{|c|}{ The Control Variables } \\
\hline LTA & Natural log of total book value of assets of the firm. \\
\hline ROE & Earnings before interest and tax to total equity of the firm. \\
\hline SALESG & Sales in current year menus sales in last year to sales of last year. \\
\hline LEVG & Total book value of debt to total book value of assets. \\
\hline$\beta$ & $\begin{array}{l}\text { Three years monthly stock returns are used to calculate Beta of firm by using a regression of } \\
\text { stock return to market returns. }\end{array}$ \\
\hline
\end{tabular}

3 Big-four refers to Deloitte \& Touche, Ernst \& Young, KPMG, and PricewaterhouseCoopers. 


\section{Appendix B}

Table A2. Pakistani CG Index (PCGI) list of provisions and measurement.

\begin{tabular}{|c|c|c|c|}
\hline CG Variables & Code & $\begin{array}{c}\text { Reference } \\
\text { CO and PCCG * }\end{array}$ & Measurement \\
\hline
\end{tabular}

\section{Board of Directors}

\begin{tabular}{|c|c|c|c|c|}
\hline 1. & $\begin{array}{l}\text { Directors Categorization } \\
\text { Disclosed in Reports }\end{array}$ & DCDA & $\begin{array}{l}\text { PCCG, } 2002 \text { (i.c) } \\
\text { LR, p. } 34(1) \\
\text { PCCG, } 2012 \text { (i) }\end{array}$ & $\begin{array}{l}\text { A binary number } 1 \text { is assigned if it } \\
\text { discloses the categorisation of } \\
\text { directors in annual reports, and } 0 \\
\text { otherwise. }\end{array}$ \\
\hline 2. & $\begin{array}{l}\text { Board Composition (Ratio of } \\
\text { Independent Directors) }\end{array}$ & BCOM & $\begin{array}{l}\text { PCCG, } 2002 \text { (i.b) } \\
\text { PCCG, } 2012 \text { (i.b) }\end{array}$ & $\begin{array}{l}\text { A binary number of } 1 \text { is assigned } \\
\text { if at least one member of the board } \\
\text { is independent, and } 0 \text { otherwise. }\end{array}$ \\
\hline 3. & $\begin{array}{l}\text { Director Representing } \\
\text { Minority Shareholders }\end{array}$ & DRMS & $\begin{array}{l}\text { PC, } 2002 \text { (i.a) } \\
\text { PCCG, } 2012 \text { (i.a) }\end{array}$ & $\begin{array}{l}\text { A binary number } 1 \text { is assigned if } \\
\text { director representing minority } \\
\text { shareholders, and } 0 \text { otherwise. }\end{array}$ \\
\hline 4. & $\begin{array}{l}\text { Board Classification (Ratio } \\
\text { of Non-Executive Directors) }\end{array}$ & RNED & $\begin{array}{l}\text { PC, } 2002 \text { (i.c) } \\
\text { PCCG, } 2012 \text { (i.d) }\end{array}$ & $\begin{array}{l}\text { A binary number of } 1 \text { if at least } \\
\text { one-fourth of the board is } \\
\text { non-executive, and } 0 \text { otherwise. }\end{array}$ \\
\hline 5. & $\begin{array}{l}\text { The Membership of } \\
\text { Directors in Other Boards }\end{array}$ & MDOB & $\begin{array}{l}\text { PC, } 2002 \text { (iii) } \\
\text { PCCG, } 2012 \text { (ii) }\end{array}$ & $\begin{array}{l}\text { Binary number } 1 \text { is assigned if it } \\
\text { discloses the director's } \\
\text { membership in other boards of } \\
\text { listed companies in their annual } \\
\text { reports, and } 0 \text { otherwise. }\end{array}$ \\
\hline 6. & $\begin{array}{l}\text { Maximum Directorship in } \\
\text { Other Boards of } \\
\text { Listed Companies }\end{array}$ & MDSB & $\begin{array}{l}\text { PCCG, } 2002 \text { (iii) } \\
\text { PCCG, } 2012 \text { (ii) }\end{array}$ & $\begin{array}{l}\text { Binary number } 1 \text { is assigned if } \\
\text { directors are not serving at the } \\
\text { same time for the board of more } \\
\text { than ten/seven, and } 0 \text { otherwise. }\end{array}$ \\
\hline 7. & Non-Executive Chairman & $\mathrm{NECH}$ & $\begin{array}{l}\text { PCCG, } 2002 \text { (ix) } \\
\text { PCCG, } 2012 \text { (vi) }\end{array}$ & $\begin{array}{l}\text { Binary number } 1 \text { is assigned if the } \\
\text { chairman of the board is a } \\
\text { non-executive director, and } 0 \\
\text { otherwise. }\end{array}$ \\
\hline 8. & $\begin{array}{l}\text { Clear Definition of } \\
\text { Respective Role of Chairman } \\
\text { and } \mathrm{CEO}^{5}\end{array}$ & & $\begin{array}{l}\text { PCCG, } 2002 \text { (ix) } \\
\text { PCCG, } 2012 \text { (vi) }\end{array}$ & $\begin{array}{l}\text { Binary number } 1 \text { is assigned if } \\
\text { there is a description that } \\
\text { categorises the role of chairman } \\
\text { and CEO, and } 0 \text { otherwise. }\end{array}$ \\
\hline 9. & CEO Duality Role & CEOD & $\begin{array}{l}\text { PCCG, } 2002 \text { (ix) } \\
\text { PCCG, } 2012 \text { (vi) }\end{array}$ & $\begin{array}{l}\text { Binary number } 1 \text { is assigned if the } \\
\text { chairman position is separate from } \\
\text { the } C E O \text {, and } 0 \text { otherwise. }\end{array}$ \\
\hline 10. & $\begin{array}{l}\text { Orientation Courses for the } \\
\text { Directors to enable them to } \\
\text { Manage the Affairs on } \\
\text { Behalf of Shareholders }\end{array}$ & OCDS & $\begin{array}{l}\text { PCCG, } 2002 \text { (xiv) } \\
\text { PCCG, } 2012 \text { (xi) }\end{array}$ & $\begin{array}{l}\text { A binary number of } 1 \text { if the firm } \\
\text { discloses the directors' attendance } \\
\text { in the orientation course, and } 0 \\
\text { otherwise. }\end{array}$ \\
\hline 11. & Board Meeting Disclosure & BRMD & $\begin{array}{l}\text { PCCG, } 2002(x i) \\
\text { PCCG, } 2012(x v i, h)\end{array}$ & $\begin{array}{l}\text { A binary number of } 1 \text { if the board } \\
\text { meetings are disclosed in annual } \\
\text { reports, and } 0 \text { otherwise. }\end{array}$ \\
\hline
\end{tabular}


Table A2. Cont.

\begin{tabular}{|c|c|c|c|c|}
\hline & CG Variables & Code & $\begin{array}{c}\text { Reference } \\
\mathrm{CO} \text { and PCCG * }\end{array}$ & Measurement \\
\hline 12. & Board Meeting Frequency & BRMF & $\begin{array}{l}\text { PCCG, } 2002 \text { (xi) } \\
\text { PCCG, } 2012(x v i, h)\end{array}$ & $\begin{array}{l}\text { A binary number of } 1 \text { if the board } \\
\text { meets at least four times in a year, } \\
\text { and } 0 \text { otherwise. }\end{array}$ \\
\hline 13. & National Tax Payer Director & NTPD & $\begin{array}{l}\text { PCCG, } 2002(\mathrm{iv}, \mathrm{a}) \\
\text { PCCG, } 2012(\mathrm{xi}, 3)\end{array}$ & $\begin{array}{l}\text { A binary number of } 1 \text { if the name } \\
\text { of the directors is born on the } \\
\text { register of National Tax Payers is } \\
\text { disclosed, and } 0 \text { otherwise. }\end{array}$ \\
\hline 14. & $\begin{array}{l}\text { No Defaulter Director in } \\
\text { the Board }\end{array}$ & NDDB & $\begin{array}{l}\text { PCCG, } 2002(i v, b) \\
\text { PCCG, } 2012(x i, 3)\end{array}$ & $\begin{array}{l}\text { A binary number of } 1 \text { if no } \\
\text { defaulter information about } \\
\text { directors is disclosed, and } 0 \\
\text { otherwise. }\end{array}$ \\
\hline 15. & $\begin{array}{l}\text { Directors and their Spouses } \\
\text { involvement in } \\
\text { Brokerage Business }\end{array}$ & DSBB & $\begin{array}{l}\text { PCCG, } 2002 \text { (xix, j) } \\
\text { PCCG, } 2012(x v i, 1)\end{array}$ & $\begin{array}{l}\text { Binary number } 1 \text { is assigned if no } \\
\text { director's involvement in } \\
\text { brokerage business is disclosed in } \\
\text { annual reports, and } 0 \text { otherwise. }\end{array}$ \\
\hline 16. & $\begin{array}{l}\text { Statement of ethics and } \\
\text { Business Practices }\end{array}$ & SEBP & $\begin{array}{l}\text { PCCG, } 2002 \text { (viii, a) } \\
\text { PCCG, } 2012 \text { (xxxiv) }\end{array}$ & $\begin{array}{l}\text { A binary number of } 1 \text { if firm } \\
\text { discloses that the statement of } \\
\text { ethics and business practices is } \\
\text { prepared and circulated, and } 0 \\
\text { otherwise. }\end{array}$ \\
\hline 17. & $\begin{array}{l}\text { Power and duties of Board } \\
\text { of Directors (BOD) }\end{array}$ & PBOD & $\begin{array}{l}\text { PC, } 2002 \text { (vii) } \\
\text { PCCG, } 2012 \text { (iv) }\end{array}$ & $\begin{array}{l}\text { Binary number } 1 \text { is assigned if it } \\
\text { discloses their fiduciary powers } \\
\text { are exercised by the board of } \\
\text { directors, and } 0 \text { otherwise. }\end{array}$ \\
\hline 18. & Future outlook & FUTO & $\begin{array}{l}\text { PCCG, } 2002(x i x, f) \\
\text { PCCG, } 2012(x v i, f)\end{array}$ & $\begin{array}{l}\text { Binary number } 1 \text { is assigned if it } \\
\text { discloses the future outlook by } \\
\text { board members, and } 0 \text { otherwise. }\end{array}$ \\
\hline \multicolumn{5}{|c|}{ Committees and Auditing } \\
\hline 19. & $\begin{array}{l}\text { Existence of } \\
\text { R\&HR }^{6} \text { Committee }\end{array}$ & RHRC & $\begin{array}{l}\text { PCCG, } 2002(x x x) \\
\text { PCCG, } 2012(x x v)\end{array}$ & $\begin{array}{l}\text { Binary number } 1 \text { is assigned if it } \\
\text { has HR committee or a } \\
\text { remuneration one, } 0 \text { otherwise. }\end{array}$ \\
\hline 20. & Committee Composition & CCOM & $\begin{array}{l}\text { PCCG, } 2002(x x x) \\
\text { PCCG, } 2012(x x v)\end{array}$ & $\begin{array}{l}\text { A binary number of } 1 \text { is assigned } \\
\text { if committee has at least three } \\
\text { members with a majority of } \\
\text { non-executive directors, and } 0 \\
\text { otherwise. }\end{array}$ \\
\hline 21. & $\begin{array}{l}\text { Committee Meetings held } \\
\text { During the Year }\end{array}$ & CMDY & $\begin{array}{l}\text { PCCG, } 2002(x x x i) \\
\text { PCCG, } 2012(x x v)\end{array}$ & $\begin{array}{l}\text { Binary number } 1 \text { is assigned if it } \\
\text { discloses different committees' } \\
\text { meetings with numbers held } \\
\text { during the year, and } 0 \text { otherwise. }\end{array}$ \\
\hline 22. & $\begin{array}{l}\text { Committee Meeting } \\
\text { Attended by each Directors }\end{array}$ & CMAD & $\begin{array}{l}\text { PCCG, } 2002(x x x) \\
\text { LR p. } 27(16 a 2) \\
\text { PCCG, } 2012(16 h)\end{array}$ & $\begin{array}{l}\text { Binary number } 1 \text { is assigned if it } \\
\text { discloses committees' meetings } \\
\text { attended by each director, and } 0 \\
\text { otherwise. }\end{array}$ \\
\hline 23. & $\begin{array}{l}\text { The Names of the Members } \\
\text { of the Committees of } \\
\text { the Boards }\end{array}$ & NMCB & $\begin{array}{l}\text { PC } 2002 \text { p. } 6(x x x) \\
\text { LR p. } 29(26) \\
\text { PCCG, } 2012(x x v i)\end{array}$ & $\begin{array}{l}\text { Binary number } 1 \text { is assigned if it } \\
\text { discloses the names of member } \\
\text { who attended committees of the } \\
\text { board in each annual report, and } 0 \\
\text { otherwise. }\end{array}$ \\
\hline
\end{tabular}


Table A2. Cont.

\begin{tabular}{|c|c|c|c|c|}
\hline & CG Variables & Code & $\begin{array}{c}\text { Reference } \\
\text { CO and PCCG * }\end{array}$ & Measurement \\
\hline 24. & $\begin{array}{l}\text { Existence and Disclosure of } \\
\text { Audit Committee Members } \\
\text { in Annual Reports }\end{array}$ & EDAC & $\begin{array}{l}\text { PCCG, } 2002(x x x) \\
\text { PCCG, } 2012(\text { xxiv) }\end{array}$ & $\begin{array}{l}\text { A binary number of } 1 \text { is assigned } \\
\text { if the names of the audit } \\
\text { committee are disclosed in annual } \\
\text { reports, and } 0 \text { otherwise. }\end{array}$ \\
\hline 25. & $\begin{array}{l}\text { Minimum Members of } \\
\text { Audit Committee }\end{array}$ & MMAC & $\begin{array}{l}\text { PCCG, } 2002(x x x) \\
\text { PCCG, } 2012(\text { xxiv) }\end{array}$ & $\begin{array}{l}\text { A binary number of } 1 \text { is assigned } \\
\text { if minimum members of audit } \\
\text { committee is at least three, and } 0 \\
\text { otherwise. }\end{array}$ \\
\hline 26. & $\begin{array}{l}\text { Non-Executive Chairman of } \\
\text { the Committee }\end{array}$ & NECC & $\begin{array}{l}\text { PCCG, } 2002(\text { xxx) } \\
\text { PCCG, } 2012 \text { (xxiv) }\end{array}$ & $\begin{array}{l}\text { A binary number of } 1 \text { if } \\
\text { con-executive director is the } \\
\text { chairman of the audit committee, } \\
\text { and } 0 \text { otherwise. }\end{array}$ \\
\hline 27. & $\begin{array}{l}\text { Majority of Non-Executives } \\
\text { in Audit Committee }\end{array}$ & MNEC & $\begin{array}{l}\text { PCCG, } 2002 \text { (xxx) } \\
\text { PCCG, } 2012 \text { (xxiv) }\end{array}$ & $\begin{array}{l}\text { Binary number } 1 \text { is assigned if its } \\
\text { non-executives have the majority } \\
\text { in audit committee, and } 0 \\
\text { otherwise. }\end{array}$ \\
\hline 28. & $\begin{array}{l}\text { Minimum Meetings of the } \\
\text { Audit Committee in a } \\
\text { Financial Year }\end{array}$ & MMAC & $\begin{array}{l}\text { PCCG, } 2002 \text { (xxxi) } \\
\text { PCCG, } 2012 \text { (xxvii) }\end{array}$ & $\begin{array}{l}\text { Binary number } 1 \text { is assigned if the } \\
\text { audit committee meets at least } \\
\text { four times in a year and this } \\
\text { information is available in annual } \\
\text { reports, and } 0 \text { otherwise. }\end{array}$ \\
\hline 29. & $\begin{array}{l}\text { CFO, The Head of Internal } \\
\text { Audit Committee and a } \\
\text { Representative of External } \\
\text { Auditors attendance }\end{array}$ & CIEA & $\begin{array}{l}\text { PCCG, } 2002 \text { (xxxii) } \\
\text { PCCG, } 2012 \text { (xxviii) }\end{array}$ & $\begin{array}{l}\text { Binary number } 1 \text { is assigned if the } \\
\text { CFO, the Head of Internal Audit } \\
\text { Committee and a Representative } \\
\text { of External Auditors attended } \\
\text { audit committee meetings and this } \\
\text { information is disclosed in annual } \\
\text { reports, and } 0 \text { otherwise. }\end{array}$ \\
\hline 30. & $\begin{array}{l}\text { Review of quarterly, } \\
\text { half-yearly and annual } \\
\text { financial statements prior to } \\
\text { the approval of the board } \\
\text { of directors }\end{array}$ & RQHY & $\begin{array}{l}\text { PCCG, } 2002 \\
\text { (xxxiii, c) } \\
\text { PCCG, } 2012 \\
(x x i x, b)\end{array}$ & $\begin{array}{l}\text { A binary number of } 1 \text { if audit } \\
\text { committee reviews quarterly, } \\
\text { half-yearly, and annual financial } \\
\text { statements prior to the approval of } \\
\text { board of directors and discloses in } \\
\text { annual reports, and } 0 \text { otherwise. }\end{array}$ \\
\hline 31. & $\begin{array}{l}\text { Review of Management } \\
\text { letter issued by the } \\
\text { external auditor }\end{array}$ & RMLE & $\begin{array}{l}\text { PCCG, } 2002 \\
\text { (xxxiii, e) } \\
\text { PCCG, } 2012 \\
\text { (xxix, e) }\end{array}$ & $\begin{array}{l}\text { A binary number of } 1 \text { if Review of } \\
\text { Management letter issued by } \\
\text { external auditors and discloses in } \\
\text { annual reports, and } 0 \text { otherwise. }\end{array}$ \\
\hline 32. & $\begin{array}{l}\text { Appointment of Secretary by } \\
\text { the Committee of Audit }\end{array}$ & ASAC & $\begin{array}{l}\text { PCCG, } 2002 \text { (xxxiv) } \\
\text { PCCG, } 2012(x x x)\end{array}$ & $\begin{array}{l}\text { Binary number } 1 \text { is assigned if its } \\
\text { audit committee appointed a } \\
\text { secretary and this information is } \\
\text { disclosed in the annual reports, } \\
\text { and } 0 \text { otherwise. }\end{array}$ \\
\hline \multicolumn{5}{|c|}{ Right of Shareholder and Annual General Meeting } \\
\hline 33. & $\begin{array}{l}\text { Notice of the Annual } \\
\text { General Meeting (AGM) } \\
\text { to shareholders }\end{array}$ & NAGM & $\begin{array}{l}\text { CO } 1984 \text { p.111 } \\
(160 a)\end{array}$ & $\begin{array}{l}\text { Binary number } 1 \text { is assigned if } \\
\text { they issued a notice of AGM about } \\
\text { the meeting to shareholders, and } 0 \\
\text { otherwise. }\end{array}$ \\
\hline
\end{tabular}


Table A2. Cont.

\begin{tabular}{|c|c|c|c|c|}
\hline & CG Variables & Code & $\begin{array}{c}\text { Reference } \\
\mathrm{CO} \text { and PCCG * }\end{array}$ & Measurement \\
\hline 34. & $\begin{array}{l}\text { Well in Time Notice of the } \\
\text { AGM to shareholders }\end{array}$ & WITN & $\begin{array}{l}\text { CO } 1984 \text { p.111 } \\
(160 a)\end{array}$ & $\begin{array}{l}\text { Binary number } 1 \text { is assigned if } \\
\text { they issued a notice of AGM at } \\
\text { least } 21 \text { days before the meeting } \\
\text { date, and } 0 \text { otherwise. }\end{array}$ \\
\hline 35. & $\begin{array}{l}\text { AGM within a Period of } \\
\text { Four Months Following the } \\
\text { Close of it Financial Year }\end{array}$ & AFFY & $\begin{array}{l}\text { CO 1984 p.108 } \\
(158 / 1)\end{array}$ & $\begin{array}{l}\text { Binary number } 1 \text { is assigned if it } \\
\text { held AGM within three/four } 7 \\
\text { months following the close of its } \\
\text { financial year, and } 0 \text { otherwise. }\end{array}$ \\
\hline 36. & $\begin{array}{l}\text { AGM in the same Town as } \\
\text { Registered Office of } \\
\text { the Company }\end{array}$ & ASRO & $\begin{array}{l}\text { CO } 1984 \text { p.108 } \\
(158 / 2)\end{array}$ & $\begin{array}{l}\text { Binary number } 1 \text { is assigned if the } \\
\text { firm held AGM within the same } \\
\text { town as the company has a } \\
\text { registered office, and } 0 \text { otherwise. }\end{array}$ \\
\hline 37. & $\begin{array}{l}\text { Notice of the Meeting with } \\
\text { Specifying the Following } \\
\text { Details }^{8}\end{array}$ & NMFD & $\begin{array}{l}\text { CO 1984 p.111 } \\
(160 / 1 a)\end{array}$ & $\begin{array}{l}\text { A binary number of } 1 \text { if the notice } \\
\text { of the AGM specifies the date, } \\
\text { place, time, and the business to be } \\
\text { transacted, and } 0 \text { otherwise. }\end{array}$ \\
\hline 38. & $\begin{array}{l}\text { Right of Shareholder to } \\
\text { Appoint a Proxy for AGM to } \\
\text { Vote for Directors }\end{array}$ & RSAP & $\begin{array}{l}\text { CO } 1984 \text { p.111 } \\
(160 / 1 d)\end{array}$ & $\begin{array}{l}\text { A binary number of } 1 \text { if the notice } \\
\text { of the AGM specify that } \\
\text { shareholder can participate } \\
\text { personally or through a proxy, } \\
\text { and } 0 \text { otherwise. }\end{array}$ \\
\hline \multicolumn{5}{|c|}{ Transparency and Disclosures } \\
\hline 39. & $\begin{array}{l}\text { Disclosure of } \\
\text { Ownership pattern }\end{array}$ & DOWS & $\begin{array}{l}\text { PCCG, } 2002(x i x, i) \\
\text { PCCG, } 2012(x v i, j)\end{array}$ & $\begin{array}{l}\text { Binary number } 1 \text { is assigned if it } \\
\text { publishes ownership pattern } \\
\text { reports, and } 0 \text { otherwise. }\end{array}$ \\
\hline 40. & $\begin{array}{l}\text { Directors, CEO, their Spouse } \\
\text { and Minor Children's' } \\
\text { Ownership Disclosure }\end{array}$ & BDOD & $\begin{array}{l}\text { PCCG, } 2002(x i x, i) \\
\text { PCCG, } 2012(x v i, j)\end{array}$ & $\begin{array}{l}\text { A binary number of } 1 \text { if a firm } \\
\text { discloses the name-wise details of } \\
\text { shareholdings of directors, CEO, } \\
\text { their spouse, and their minor } \\
\text { children's, and } 0 \text { otherwise. }\end{array}$ \\
\hline 41. & $\begin{array}{l}\text { Shareholding Ten/five }{ }^{9} \\
\text { Percent or More } \\
\text { Voting Rights }\end{array}$ & STMV & $\begin{array}{l}\text { PCCG, } 2002(x i x, i) \\
\text { PCCG, } 2012(x v i, j)\end{array}$ & $\begin{array}{l}\text { A binary number of } 1 \text { if firm } \\
\text { discloses the shareholdings of } \\
\text { ten/five per cent or more voting } \\
\text { rights, and } 0 \text { otherwise. }\end{array}$ \\
\hline 42. & $\begin{array}{l}\text { Going Concern Disclosure in } \\
\text { Annual Reports }\end{array}$ & GCDR & $\begin{array}{l}\text { PCCG, } 2002 \text { (xix, a) } \\
\text { PCCG, } 2012(x v i, f)\end{array}$ & $\begin{array}{l}\text { A binary number of } 1 \text { if it is } \\
\text { disclosed that the firm is a going } \\
\text { concern entity and explanation if } \\
\text { not, and } 0 \text { otherwise. }\end{array}$ \\
\hline 43. & $\begin{array}{l}\text { Outstanding Taxes and } \\
\text { Other Charges disclosed }\end{array}$ & OTOC & $\begin{array}{l}\text { PCCG, } 2002 \text { (xix, e) } \\
\text { PCCG, } 2012(x v i, e)\end{array}$ & $\begin{array}{l}\text { Binary number } 1 \text { is assigned if it } \\
\text { discloses its outstanding taxes and } \\
\text { other charges with reason in } \\
\text { annual reports, and } 0 \text { otherwise. }\end{array}$ \\
\hline 44. & $\begin{array}{l}\text { Presentation of Operations, } \\
\text { Cash Flows, and Change } \\
\text { in Equity }\end{array}$ & POCE & $\begin{array}{l}\text { PCCG, } 2002 \text { (xix, a) } \\
\text { PCCG, } 2012(x v i, a)\end{array}$ & $\begin{array}{l}\text { Binary number } 1 \text { is assigned if it } \\
\text { discloses the operations, } \\
\text { cash flows, and change in equity } \\
\text { in annual reports, and } 0 \text { otherwise. }\end{array}$ \\
\hline
\end{tabular}


Table A2. Cont.

\begin{tabular}{|c|c|c|c|c|}
\hline & CG Variables & Code & $\begin{array}{c}\text { Reference } \\
\mathrm{CO} \text { and PCCG * }\end{array}$ & Measurement \\
\hline 45. & $\begin{array}{l}\text { Key Operating and Financial } \\
\text { Data for Last Six Years }\end{array}$ & OFSY & $\begin{array}{l}\text { PCCG, } 2002(x i x, c) \\
\text { PCCG, } 2012(x v i, c)\end{array}$ & $\begin{array}{l}\text { Binary number } 1 \text { is assigned if it } \\
\text { discloses the last six years } \\
\text { financial and operating } \\
\text { performance in annual reports, } \\
\text { and } 0 \text { otherwise. }\end{array}$ \\
\hline 46. & $\begin{array}{l}\text { Significant Deviation from } \\
\text { Last Year } \\
\text { Operating Outcomes }\end{array}$ & SDOR & $\begin{array}{l}\text { PCCG, } 2002(x i x, b) \\
\text { PCCG, } 2012(x v i, b)\end{array}$ & $\begin{array}{l}\text { Binary number } 1 \text { is assigned if it } \\
\text { discloses operating results and } \\
\text { significant deviation from last } \\
\text { year, if any, and the reasons are } \\
\text { explained in annual reports, and } 0 \\
\text { otherwise. }\end{array}$ \\
\hline 47. & $\begin{array}{l}\text { Trades of Share Carried out } \\
\text { by the director and Other } \\
\text { Executives }^{10}\end{array}$ & TSDE & $\begin{array}{l}\text { PCCG, } 2002(x i x, j) \\
\text { LR p. } 28(161) \\
\text { PCCG, } 2012(x v i, 1)\end{array}$ & $\begin{array}{l}\text { Binary number } 1 \text { is assigned if it } \\
\text { discloses the trade of shares of } \\
\text { companies carried out by } \\
\text { directors, executives, } \\
\text { their spouses, and their minor } \\
\text { child, and } 0 \text { otherwise. }\end{array}$ \\
\hline 48. & $\begin{array}{l}\text { Disclosure of Objectives and } \\
\text { Corporate Strategy }\end{array}$ & DOCS & $\begin{array}{l}\text { PCCG, } 2002(\text { viii, b) } \\
\text { PCCG, } 2012(v, c)\end{array}$ & $\begin{array}{l}\text { A binary number of } 1 \text { if firm } \\
\text { discloses mission, vision, } \\
\text { and corporate strategies in annual } \\
\text { reports, and } 0 \text { otherwise. }\end{array}$ \\
\hline 49. & $\begin{array}{l}\text { Statement on Compliance } \\
\text { with Corporate } \\
\text { Governance Code }\end{array}$ & SCCG & $\begin{array}{l}\text { PCCG, } 2002(x l v) \\
\text { LR p. } 34(11) \\
\text { PCCG, } 2012(x l)\end{array}$ & $\begin{array}{l}\text { Binary number } 1 \text { is assigned if it } \\
\text { provides a positive statement on } \\
\text { PCCG }^{11} \text { in the reports, and } 0 \\
\text { otherwise. }\end{array}$ \\
\hline 50. & $\begin{array}{l}\text { Disclosure of Dividend } \\
\text { Policy (Reason for any } \\
\text { bonus share or no dividend) }\end{array}$ & DODP & $\begin{array}{l}\text { PCCG, } 2002(x i x, d) \\
\text { PCCG, } 2012(x v i, d)\end{array}$ & $\begin{array}{l}\text { Binary number } 1 \text { is assigned if it } \\
\text { discloses the reason for a bonus } \\
\text { share (if any) or not paying a } \\
\text { dividend, and } 0 \text { otherwise. }\end{array}$ \\
\hline 51. & $\begin{array}{l}\text { Disclosure of Detail of } \\
\text { Related Party Transaction }\end{array}$ & DRPT & $\begin{array}{l}\text { PCCG, } 2002(x i i i, b) \\
\text { PCCG, } 2012(x)\end{array}$ & $\begin{array}{l}\text { A binary number of } 1 \text { if firm } \\
\text { discloses facts of any contract in } \\
\text { which executives or any director } \\
\text { was an interested and clear } \\
\text { statement in case of no such } \\
\text { transaction, and } 0 \text { otherwise. }\end{array}$ \\
\hline 52. & $\begin{array}{l}\text { Director's Detailed } \\
\text { Remuneration Disclosure }\end{array}$ & DDRD & $\begin{array}{l}\text { PCCG, } 2012 \text { (xvii, } \\
\text { b) }\end{array}$ & $\begin{array}{l}\text { Binary number } 1 \text { is assigned if it } \\
\text { publishes board members' } \\
\text { remuneration in annual reports, } \\
\text { and } 0 \text { otherwise. }\end{array}$ \\
\hline
\end{tabular}

2. Internal Control, External Auditor, and Risk Management

53. Presence of Effective Internal Control System

EICS PCCG, 2002 (viii, c) and sound internal control system PCCG, 2012 (xxix, i) established, implemented, and monitored by the BOD, and 0 otherwise.

Binary number 1 is assigned if it

54. Disclosure of Firm Risk in Annual Reports
PCCG, 2002 (xix, f) PCCG, 2012 (ix) offers an explanation of the actual and potential risk of the company, and 0 otherwise. 
Table A2. Cont.

\begin{tabular}{|c|c|c|c|c|}
\hline & CG Variables & Code & $\begin{array}{c}\text { Reference } \\
\mathrm{CO} \text { and } \mathrm{PCCG} *\end{array}$ & Measurement \\
\hline 55. & $\begin{array}{l}\text { Risk Management Policies } \\
\text { by the BOD }\end{array}$ & RMPB & $\begin{array}{l}\text { PCCG, } 2002 \text { (viii, b) } \\
\text { PCCG, } 2012 \text { (ix) }\end{array}$ & $\begin{array}{l}\text { A binary number of } 1 \text { if the firm } \\
\text { provides a clear description of risk } \\
\text { management policies in the } \\
\text { annual report, and } 0 \text { otherwise. }\end{array}$ \\
\hline 56. & $\begin{array}{l}\text { Auditor review of Internal } \\
\text { Control System }\end{array}$ & ARIS & $\begin{array}{l}\text { PCCG, } 2002 \\
(\text { xxxiii, j) } \\
\text { PCCG, } 2012 \text { (xiv, d) }\end{array}$ & $\begin{array}{l}\text { A binary number of } 1 \text { if auditor } \\
\text { reports provide a narrative that } \\
\text { internal control system has been } \\
\text { reviewed by the auditor, and } 0 \\
\text { otherwise. }\end{array}$ \\
\hline 57. & $\begin{array}{l}\text { Auditor Review of Firm } \\
\text { Financial Reports }\end{array}$ & ARFR & $\begin{array}{l}\text { PCCG, } 2002 \\
\text { (xxxiii, c) } \\
\text { PCCG, } 2012 \\
(x x i x, b)\end{array}$ & $\begin{array}{l}\text { Binary number } 1 \text { is assigned if its } \\
\text { auditor reports provide } \\
\text { description financial reports have } \\
\text { been reviewed by the auditor, } \\
\text { and } 0 \text { otherwise. }\end{array}$ \\
\hline 58. & $\begin{array}{l}\text { Approval of Firm } \\
\text { Financial Reports }\end{array}$ & AFFR & $\begin{array}{l}\text { PCCG, } 2002 \text { (xxiv) } \\
\text { PCCG, } 2012 \text { (xxi) }\end{array}$ & $\begin{array}{l}\text { Binary number } 1 \text { is assigned if its } \\
\text { reports are ratified by BOD and } \\
\text { signed by the authorised } \\
\text { executives, CFO, and CEO earlier } \\
\text { than rotation, and } 0 \text { otherwise. }\end{array}$ \\
\hline 59. & $\begin{array}{l}\text { Proper Book of } \\
\text { Account Maintained }\end{array}$ & PBAM & $\begin{array}{l}\text { PCCG, } 2002 \text { (xix, b) } \\
\text { PCCG, } 2012(x v i, b)\end{array}$ & $\begin{array}{l}\text { Binary number } 1 \text { is assigned if it } \\
\text { publishes that proper book of } \\
\text { accounts is maintained in annual } \\
\text { reports, and } 0 \text { otherwise. }\end{array}$ \\
\hline 60. & $\begin{array}{l}\text { Appropriate Accounting } \\
\text { Policies Applied in } \\
\text { Preparation of Accounting } \\
\text { Estimations and } \\
\text { Financial Statement }\end{array}$ & APAE & $\begin{array}{l}\text { PCCG, } 2002(x i x, c) \\
\text { PCCG, } 2012(x v i, c)\end{array}$ & $\begin{array}{l}\text { Binary number } 1 \text { is assigned if it } \\
\text { discloses appropriate accounting } \\
\text { rules applied in the preparation of } \\
\text { accounting estimations and } \\
\text { financial statements in annual } \\
\text { reports, and } 0 \text { otherwise. }\end{array}$ \\
\hline 61. & $\begin{array}{l}\text { Financial Statements } \\
\text { According to } \text { IAS }^{12}\end{array}$ & FIAS & $\begin{array}{l}\text { PCCG, } 2002 \text { (xix, d) } \\
\text { PCCG, } 2012 \text { (xxix) }\end{array}$ & $\begin{array}{l}\text { A binary number of } 1 \text { if firm } \\
\text { discloses that financial statements } \\
\text { are according to IAS, and } 0 \\
\text { otherwise. }\end{array}$ \\
\hline 62. & $\begin{array}{l}\text { External Auditor's } \\
\text { Satisfactory Rating by } \\
\text { Institute of Charted } \\
\text { Accountants of Pakistan }\end{array}$ & EARI & $\begin{array}{l}\text { PCCG, } 2002 \text { (xxxvii) } \\
\text { PCCG, } 2012 \text { (xxxiii) }\end{array}$ & $\begin{array}{l}\text { A binary number of } 1 \text { if external } \\
\text { auditors have satisfactory rating } \\
\text { under the Quality Review } \\
\text { Program by Institute of Charted } \\
\text { Accountants of Pakistan and this } \\
\text { information is disclosed, and } 0 \\
\text { otherwise. }\end{array}$ \\
\hline 63. & $\begin{array}{l}\text { Compliance with IFAC }{ }^{13} \\
\text { Gridlines on Code of Ethics } \\
\text { as Adopted by ICAP }{ }^{14} \text {. }\end{array}$ & CGCE & $\begin{array}{l}\text { PCCG }, 2002 \\
\text { (xxxviii) } \\
\text { PCCG, } 2012 \text { (xxxiii) }\end{array}$ & $\begin{array}{l}\text { A binary number of } 1 \text { is assigned } \\
\text { if compliance with International } \\
\text { Federation of Accountants } \\
\text { Gridlines on code of ethics is } \\
\text { published in annual reports, and } 0 \\
\text { otherwise. }\end{array}$ \\
\hline 64. & $\begin{array}{l}\text { Auditor Duties According } \\
\text { to IFAC }\end{array}$ & ADIM & $\begin{array}{l}\text { PCCG, } 2002 \text { (xl) } \\
\text { PCCG, } 2012 \text { (xxxiv) }\end{array}$ & $\begin{array}{l}\text { A binary number of } 1 \text { is assigned } \\
\text { if the auditor performs duties } \\
\text { according to IFAC, } \\
\text { no management role, and this } \\
\text { information is disclosed in annual } \\
\text { reports, and } 0 \text { otherwise. }\end{array}$ \\
\hline
\end{tabular}


Table A2. Cont.

\begin{tabular}{|c|c|c|c|c|}
\hline & CG Variables & Code & $\begin{array}{c}\text { Reference } \\
\mathrm{CO} \text { and PCCG * }\end{array}$ & Measurement \\
\hline 65. & $\begin{array}{l}\text { Attendance of } \mathrm{AGM}^{15} \text { by } \\
\text { external Auditor }\end{array}$ & AAGM & $\begin{array}{l}\text { PCCG, } 2002 \text { (xliv) } \\
\text { PCCG, } 2012 \text { (xli) }\end{array}$ & $\begin{array}{l}\text { A binary number of } 1 \text { is assigned } \\
\text { if external auditor of the company } \\
\text { attends the annual general } \\
\text { meeting and this information is } \\
\text { disclosed in annual reports, and } 0 \\
\text { otherwise. }\end{array}$ \\
\hline 66. & $\begin{array}{l}\text { Statutory Auditor's Review } \\
\text { of Corporate Governance } \\
\text { Compliance Statement }\end{array}$ & SARC & $\begin{array}{l}\text { PCCG, } 2002 \text { (xlvi) } \\
\text { PCCG, } 2012 \text { (xli) }\end{array}$ & $\begin{array}{l}\text { A binary number of } 1 \text { is assigned } \\
\text { if statutory auditors of company } \\
\text { review the Corporate Governance } \\
\text { Compliance Statement and } \\
\text { disclose this information in annual } \\
\text { reports, and } 0 \text { otherwise. }\end{array}$ \\
\hline 67. & $\begin{array}{l}\text { Half-yearly financial } \\
\text { statements with statutory } \\
\text { auditor's review }\end{array}$ & HYFS & $\begin{array}{l}\text { PCCG, } 2002(x x i) \\
\text { PCCG, } 2012 \\
(x x i x, b)\end{array}$ & $\begin{array}{l}\text { A binary number of } 1 \text { is assigned } \\
\text { if half-yearly financial statements } \\
\text { with statutory auditor's review } \\
\text { information are disclosed in } \\
\text { annual reports, and } 0 \text { otherwise. }\end{array}$ \\
\hline 68. & $\begin{array}{l}\text { Annual audited financial } \\
\text { statements not later than } \\
\text { four-month from the close of } \\
\text { the financial year }\end{array}$ & AAFS & $\begin{array}{l}\text { PCCG, } 2002 \text { (xxii) } \\
\text { PCCG, } 2012 \\
\text { (xxix) }\end{array}$ & $\begin{array}{l}\text { A binary number of } 1 \text { if annual } \\
\text { audited financial statements no } \\
\text { later than four months from the } \\
\text { close of financial year are disclose } \\
\text { in annual reports, and } 0 \text { otherwise. }\end{array}$ \\
\hline 69. & $\begin{array}{l}\text { Determination of } \\
\text { Compliance with relevant } \\
\text { Statutory Requirements }\end{array}$ & DCSR & $\begin{array}{l}\text { PCCG }, 2002(x x x, 1) \\
\text { PCCG, } 2012 \\
(x x i x, 1)\end{array}$ & $\begin{array}{l}\text { A binary number of } 1 \text { is assigned } \\
\text { if compliance with relevant } \\
\text { statutory requirements is } \\
\text { determined by external auditors } \\
\text { and is disclosed in annual reports, } \\
\text { and } 0 \text { otherwise. }\end{array}$ \\
\hline 70. & $\begin{array}{l}\text { Monitoring Compliance } \\
\text { with Best Practices of } \\
\text { Corporate Governance and } \\
\text { Identification of Violence }\end{array}$ & MCGV & $\begin{array}{l}\text { PCCG, } 2002 \\
(x x x, m) \\
\text { PCCG } 2012 \\
(x x i x, m)\end{array}$ & $\begin{array}{l}\text { A binary number of } 1 \text { if external } \\
\text { auditors are Monitoring } \\
\text { Compliance with Best Practices of } \\
\text { Corporate Governance and } \\
\text { Identification of Violence if any } \\
\text { discloses in annual reports, and } 0 \\
\text { otherwise. }\end{array}$ \\
\hline
\end{tabular}

* CO stands for Companies Ordinance 1984 by Pakistani Government and PCCG stands for Pakistani Code of CG.

\footnotetext{
4 Categorization of directors in terms of independent, non-executive, or executive. Chief Executive Officer.

Remunerations and Human Resource Committee

7 According to Companies Ordinance 1984, till 2008, this period was four months and then changed to three months. Data are collected accordingly.

8 Notice of AGM to shareholders contains the date, place, time, and the business to be transacted.

9 Shareholding to be disclosed was ten percent in PCCG 2002, but it was changed to five percent shareholding in PCCG 2012.

10 Here "executives" means the CEO, COO, CFO, head of internal audit, and company secretary.

11 PCCG stands for Pakistani Code of Corporate Governance.

12 IAS stands for International Accounting Standards, and Pakistan follows these standards in preparation of financial statements.

13 IFAC stands for International Federation of Accountants and this institute issued guidelines on code of ethics.

14 ICAP stands for Institute of Charted Accountants of Pakistan, and this institute adopted the same code of ethics.

15 AGM stands for annual general meeting of a company.
} 


\section{Appendix C}

Table A3. Correlation matrix of dependent and independent variables: CG and COC model.

\begin{tabular}{|c|c|c|c|c|c|c|c|c|c|c|c|c|c|c|c|c|}
\hline & $\mathrm{COC}$ & PCGI & DOWNP & IOWNP & GOWNP & BOWNP & FOWNP & BIG4 & BSZ & BGEN & BNAT & LTA & ROE & SALESG & LVG & B \\
\hline COC & 1.000 & & & & & & & & & & & & & & & \\
\hline PCGI & -0.138 & 1.000 & & & & & & & & & & & & & & \\
\hline DOWNP & -0.015 & -0.010 & 1.000 & & & & & & & & & & & & & \\
\hline IOWNP & -0.013 & 0.027 & -0.163 & 1.000 & & & & & & & & & & & & \\
\hline GOWNP & 0.015 & 0.011 & -0.194 & 0.277 & 1.000 & & & & & & & & & & & \\
\hline BOWNP & -0.008 & -0.008 & -0.027 & 0.531 & 0.336 & 1.000 & & & & & & & & & & \\
\hline FOWNP & 0.079 & -0.012 & -0.265 & 0.254 & 0.264 & 0.464 & 1.000 & & & & & & & & & \\
\hline BIG4 & 0.046 & 0.062 & -0.373 & 0.092 & 0.149 & 0.066 & 0.248 & 1.000 & & & & & & & & \\
\hline BSZ & 0.003 & 0.025 & -0.251 & 0.232 & 0.184 & 0.087 & -0.006 & 0.278 & 1.000 & & & & & & & \\
\hline BGEN & -0.009 & 0.001 & 0.275 & -0.018 & -0.077 & 0.081 & -0.022 & -0.152 & -0.097 & 1.000 & & & & & & \\
\hline BNAT & 0.028 & 0.017 & -0.435 & 0.165 & -0.002 & 0.169 & 0.408 & 0.390 & 0.122 & -0.185 & 1.000 & & & & & \\
\hline LTA & -0.120 & 0.161 & -0.036 & 0.108 & 0.071 & 0.076 & -0.054 & 0.054 & 0.086 & -0.130 & 0.066 & 1.000 & & & & \\
\hline ROE & -0.039 & -0.048 & 0.171 & 0.006 & -0.076 & 0.012 & -0.083 & -0.185 & -0.074 & 0.066 & -0.139 & -0.115 & 1.000 & & & \\
\hline SALESG & -0.042 & 0.031 & 0.051 & -0.017 & -0.017 & -0.023 & -0.033 & -0.028 & -0.002 & 0.010 & -0.007 & 0.101 & -0.004 & 1.000 & & \\
\hline LVG & -0.153 & -0.015 & 0.200 & -0.034 & -0.089 & -0.014 & -0.139 & -0.181 & -0.139 & 0.097 & -0.128 & -0.091 & 0.129 & -0.003 & 1.000 & \\
\hline B & 0.320 & 0.072 & -0.067 & -0.028 & -0.001 & 0.010 & -0.024 & 0.061 & 0.014 & 0.005 & 0.033 & 0.089 & 0.019 & -0.021 & -0.035 & 1.000 \\
\hline
\end{tabular}

Notes: PCGI denotes the Pakistani Corporate Governance Index, DOWNP represents director ownership, IOWNP represents institutional ownership, GOWNP represents government ownership, BOWNP represents block ownership, FOWNP represents foreign ownership, BIG4 represents the audit firm size, BSZ represents the size of the board of directors, BGEN represents board diversity on the basis of gender, BNAT represents board diversity on the basis of nationality, LTA represents firm size as log of total assets, ROE represents a return on equity as a measure of profitability, SALESG represents growth opportunities, LVG represents leverage, CE represents capital expenditures and $\beta$ represents the systematic risk. 


\section{References}

Abu-Tapanjeh, Abdussalam Mahmoud. 2009. Corporate governance from the Islamic perspective: A comparative analysis with OECD principles. Critical Perspectives on Accounting 20: 556-67. [CrossRef]

Aggarwal, Reena, Isil Erel, Miguel Ferreira, and Pedro Matos. 2011. Does governance travel around the world? Evidence from institutional investors. Journal of Financial Economics 100: 154-81. [CrossRef]

Ahmad, Iftikhar. 2011. Religion and labor: Perspective in Islam. Working USA 14: 589-620. [CrossRef]

Al-Abbas, Mohammed. 2009. Corporate governance and earnings management: An empirical study of the Saudi market. The Journal of American Academy of Business, Cambridge 15: 301-10.

Al-Bassam, Waleed M., Collins G. Ntim, Kwaku K. Opong, and Yvonne Downs. 2018. Corporate boards and ownership structure as antecedents of corporate governance disclosure in Saudi Arabian publicly listed corporations. Business and Society 57: 335-77. [CrossRef]

Ali Shah, Syed Zulfiqar, and Safdar A. Butt. 2009. The impact of corporate governance on the cost of equity: Empirical evidence from Pakistani listed companies. The Lahore Journal of Economics 14: 139-71. [CrossRef]

Allegrini, Marco, and Giulio Greco. 2013. Corporate boards, audit committees and voluntary disclosure: Evidence from Italian listed companies. Journal of Management \& Governance 17: 187-216.

Al-Nodel, Ali, and Khaled Hussainey. 2010. Corporate governance and financing decisions by Saudi companies. Journal of Modern Accounting and Auditing 6: 1-14.

Arslan, Muhammad, and Sazali Abidin. 2019. Nexus between corporate governance practices and cost of capital in PSX listed firms. Cogent Economics \& Finance 7: 1600222.

Bebchuk, Lucian A., and Michael S. Weisbach. 2010. The state of corporate governance research. Review of Financial Studies 23: 939-61. [CrossRef]

Beiner, Stefan, Wolfgang Drobetz, Markus M. Schmid, and Heinz Zimmermann. 2006. An integrated framework of corporate governance and firm valuation. European Financial Management 12: 249-83. [CrossRef]

Bennedsen, Morten, and Daniel Wolfenzon. 2000. The balance of power in closely held corporations. Journal of Financial Economics 58: 113-39. [CrossRef]

Bhojraj, Sanjeev, and Partha Sengupta. 2003. Effect of corporate governance on bond ratings and yields: The role of institutional investors and outside directors. The Journal of Business 76: 455-75. [CrossRef]

Bos, Auke de, and Han Donker. 2004. Monitoring accounting changes: Empirical evidence from the Netherlands. Corporate governance: An international Review 12: 60-73. [CrossRef]

Boubakri, Narjess, Omrane Guedhami, and Walid Saffar. 2016. Geographic location, foreign ownership, and cost of equity capital: Evidence from privatisation. Journal of Corporate Finance 38: 363-81. [CrossRef]

Bozec, Yves, and Richard Bozec. 2011. Corporate governance quality and the cost of capital. International Journal of Corporate Governance 2: 217-36. [CrossRef]

Bozec, Yves, and Claude Laurin. 2008. Large shareholder entrenchment and performance: Empirical evidence from Canada. Journal of Business Finance EAccounting 35: 25-49.

Bozec, Yves, Claude Laurin, and Iwan Meier. 2014. The relation between excess control and cost of capital. International Journal of Managerial Finance 10: 93-114. [CrossRef]

Chen, Kevin CW, Zhihong Chen, and KC John Wei. 2009. Legal protection of investors, corporate governance, and the cost of equity capital. Journal of Corporate Finance 15: 273-89. [CrossRef]

Chung, Kee H., and Hao Zhang. 2011. Corporate governance and institutional ownership. Journal of Financial and Quantitative Analysis 46: 247-73. [CrossRef]

Chung, Kee H., Peter Wright, and Ben Kedia. 2003. Corporate governance and market valuation of capital and R\&D investments. Review of Financial Economics 12: 161-72.

Claessen, David, André M. de Roos, and Lennart Persson. 2000. Dwarfs and giants: Cannibalism and competition in size-structured populations. The American Naturalist 155: 219-37. [CrossRef]

Claessens, Stijn, and B. Burcin Yurtoglu. 2013. Corporate governance in emerging markets: A survey. Emerging Markets Review 15: 1-33. [CrossRef]

Clarkson, Pete, Jose Guedes, and Rex Thompson. 1996. On the diversification, observability, and measurement of estimation risk. Journal of Financial \& Quantitative Analysis 31: 69-84.

Conyon, Martin J., and Lerong He. 2011. Executive compensation and corporate governance in China. Journal of Corporate Finance 17: 1158-75. [CrossRef] 
Cornett, Marcia Millon, Lin Guo, Shahriar Khaksari, and Hassan Tehranian. 2010. The impact of state ownership on performance differences in privately-owned versus state-owned banks: An international comparison. Journal of Financial Intermediation 19: 74-94. [CrossRef]

Crutchley, Claire E., Marlin RH Jensen, John S. Jahera Jr., and Jennie E. Raymond. 1999. Agency problems and the simultaneity of financial decision making: The role of institutional ownership. International Review of Financial Analysis 8: 177-97. [CrossRef]

Cumming, Douglas, Michele Meoli, and Silvio Vismara. 2019. Investors' choices between cash and voting rights: Evidence from dual-class equity crowdfunding. Research Policy 48: 103740. [CrossRef]

Demise, Nobuyuki. 2006. OECD principles of corporate governance. In Corporate Governance in Japan. Tokyo: Springer, pp. 109-17.

Demsetz, Harold, and Kenneth Lehn. 1985. The structure of corporate ownership: Causes and consequences. Journal of Political Economy 93: 1155-77. [CrossRef]

Diamond, Douglas W., and Robert E. Verrecchia. 1991. Disclosure, liquidity, and the cost of capital. The Journal of Finance 46: 1325-59. [CrossRef]

Donnelly, Ray, and Mark Mulcahy. 2008. Board structure, ownership, and voluntary disclosure in Ireland. Corporate Governance: An International Review 16: 416-29. [CrossRef]

Dyck, Alexander, and Luigi Zingales. 2004. Private benefits of control: An international comparison. The Journal of Finance 59: 537-600. [CrossRef]

Elshandidy, Tamer, and Lorenzo Neri. 2015. Corporate governance, risk disclosure practices, and market liquidity: Comparative evidence from the UK and Italy. Corporate Governance: An International Review 23: 331-56. [CrossRef]

Elston, Julie Ann, and Laura Rondi. 2007. Shareholder Protection and the Cost of Capital: Empirical Evidence from German and Italian Firms. Italian. Journal of Applied Statistics 18: 153-72. [CrossRef]

Eng, Li Li, and Yuen Teen Mak. 2003. Corporate governance and voluntary disclosure. Journal of Accounting and Public Policy 22: 325-45. [CrossRef]

Faccio, Mara, and Larry HP Lang. 2002. The ultimate ownership of Western European corporations. Journal of Financial Economics 65: 365-95. [CrossRef]

Hail, Luzi, and Christian Leuz. 2006. International differences in the cost of equity capital: Do legal institutions and securities regulation matter? Journal of Accounting Research 44: 485-531. [CrossRef]

Henry, Darren. 2008. Corporate governance structure and the valuation of Australian firms: Is there value in ticking the boxes? Journal of Business Finance \& Accounting 35: 912-42.

Hermalin, Benjamin E., and Michael S. Weisbach. 2019. Understanding corporate governance through learning models of managerial competence. Asia-Pacific Journal of Financial Studies 48: 7-29. [CrossRef]

Hooghiemstra, Reggy. 2012. What determines the informativeness of firms' explanations for deviations from the Dutch corporate governance code? Accounting and Business Research 42: 1-27. [CrossRef]

Huafang, Xiao, and Yuan Jianguo. 2007. Ownership structure, board composition and corporate voluntary disclosure: Evidence from listed companies in China. Managerial Auditing Journal 22: 604-19. [CrossRef]

Ibrahim, Ali Adnan. 2006. Corporate governance in Pakistan: Analysis of current challenges and recommendations for future reforms. Washington University Global Studies Law Review 5: 323.

Ilyas, Muhammad, and Shahid Jan. 2017. Corporate governance and cost of capital: Evidence from Pakistan. Global Management Journal for Academic and Corporate Studies 7: 10-21.

Jensen, Michael C., and William H. Meckling. 1979. Theory of the firm: Managerial behavior, agency costs, and ownership structure. In Economics Social Institutions. Dordrecht: Springer, pp. 163-231.

Khan, Muhammad Yar. 2016. Corporate Governance and Cost of Capital: Evidence from Pakistani Listed Firms. Ph.D. dissertation, University of Glasgow, Glasgow, Scotland.

Khan, Muhammad Yar, Tahira Awan, Naima Saleem, and Anam Javeed. 2017. The impact of Islamic governance mechanisms on corporate governance compliance and disclosure. Journal of Managerial Sciences 11: 399-414.

Kim, Bong Hwan. 2018. The costs of debt contracts and the repeated use of debt covenants. Asia-Pacific Journal of Financial Studies 47: 858-80. [CrossRef]

King Committee on Corporate Governance, \& Institute of Directors (South Africa). 2002. King Report on Corporate Governance for South Africa, 2002. Institute of Directors in Southern Africa: Available online: https://ecgi.global/code/king-report-corporate-governance-south-africa-2002-king-ii-report (accessed on 13 July 2020). 
Konijn, Sander JJ, Roman Kräussl, and Andre Lucas. 2011. Blockholder dispersion and firm value. Journal of Corporate Finance 17: 1330-39. [CrossRef]

La Porta, Rafael, Florencio Lopez-de-Silanes, Andrei Shleifer, and Robert Vishny. 2002. Investor protection and corporate valuation. Journal of Finance 57: 1147-70. [CrossRef]

Lim, Sonya Seongyeon, and Heli Wang. 2007. The effect of financial hedging on the incentives for corporate diversification: The role of stakeholder firm-specific investments. Journal of Economic Behavior E Organization 62: 640-56.

Lombardo, Davide, and Pagano Marco. 1999. Law and Equity Markets: A Simple Model (October). Available online: http://dx.doi.org/10.2139/ssrn.209312 (accessed on 13 July 2020).

Ntim, Collins. G., and Teerooven Soobaroyen. 2013. Corporate governance and performance in socially responsible corporations: New empirical insights from a Neo-Institutional framework. Corporate Governance: An International Review 21: 468-94. [CrossRef]

Ntim, Collins G., Kwaku K. Opong, Jo Danbolt, and Dennis A. Thomas. 2012. Voluntary corporate governance disclosures by post-Apartheid South African corporations. Journal of Applied Accounting Research 13: 122-44. [CrossRef]

Pham, Peter Kien, Jo-Ann Suchard, and Jason Zein. 2012. Corporate Governance and the Cost of Capital: Evidence from Australian Companies. Journal of Applied Corporate Finance 24: 84-93. [CrossRef]

Phung, Duc Nam, and Thi Phuong Vy Le. 2013. Foreign Ownership, Capital Structure and Firm Performance: Empirical Evidence from Vietnamese Listed Firms. IUP Journal of Corporate Governance 12: 40-58.

Piot, Charles, and Franck Missonier-Piera. 2009. Corporate governance reform and the cost of debt financing of listed French companies. Available online: https://papers.ssrn.com/sol3/papers.cfm?abstract_id=960681 (accessed on 13 July 2020).

Samaha, K., Khaled Dahawy, Khaled Hussainey, and Pamela Stapleton. 2012. The extent of corporate governance disclosure and its determinants in a developing market: The case of Egypt. Advances in Accounting 28: 168-78. [CrossRef]

Shleifer, Andrei, and Robert W. Vishny. 1986. Large shareholders and corporate control. Journal of Political Economy 94: 461-88. [CrossRef]

Shleifer, Andrei, and Robert W. Vishny. 1997. A survey of corporate governance. The Journal of Finance 52: 737-83. [CrossRef]

Siebels, Jan-Folke, and Dodo zu Knyphausen-Aufseß. 2012. A review of theory in family business research: The implications for corporate governance. International Journal of Management Reviews 14: 280-304. [CrossRef]

Smith, E. Daniel. 1976. The effect of the separation of ownership from control on accounting policy decisions. The Accounting Review 51: 707-23.

Solomon, Jill F., Shih Wei Lin, Simon D. Norton, and Aris Solomon. 2003. Corporate governance in Taiwan: Empirical evidence from Taiwanese company directors. Corporate Governance: An International Review 11: 235-48. [CrossRef]

Tariq, Yasir Bin, and Zaheer Abbas. 2013. Compliance and multidimensional firm performance: Evaluating the efficacy of rule-based code of corporate governance. Economic Modelling 35: 565-75. [CrossRef]

Tsamenyi, Mathew, Elsie Enninful-Adu, and Joseph Onumah. 2007. Disclosure and corporate governance in developing countries: Evidence from Ghana. Managerial Auditing Journal 22: 319-34. [CrossRef]

Vafeas, Nikos, and Elena Theodorou. 1998. The relationship between board structure and firm performance in the UK. The British Accounting Review 30: 38-407. [CrossRef]

Verrecchia, Robert E. 2001. Essays on disclosure. Journal of Accounting and Economics 32: 97-180. [CrossRef]

(C) 2020 by the authors. Licensee MDPI, Basel, Switzerland. This article is an open access article distributed under the terms and conditions of the Creative Commons Attribution (CC BY) license (http://creativecommons.org/licenses/by/4.0/). 